University of Chicago Law School

Chicago Unbound

Journal Articles

Faculty Scholarship

1985

\title{
Mediation with a Mugger: The Shortage of Adjudicative Services and the Need for a Two-Tier Trial System in Civil Cases
}

Albert W. Alschuler

Follow this and additional works at: https://chicagounbound.uchicago.edu/journal_articles

Part of the Law Commons

\section{Recommended Citation}

Albert Alschuler, "Mediation with a Mugger: The Shortage of Adjudicative Services and the Need for a Two-Tier Trial System in Civil Cases," 99 Harvard Law Review 1808 (1985).

This Article is brought to you for free and open access by the Faculty Scholarship at Chicago Unbound. It has been accepted for inclusion in Journal Articles by an authorized administrator of Chicago Unbound. For more information, please contact unbound@law.uchicago.edu. 


\title{
MEDIATION WITH A MUGGER: THE SHORTAGE OF ADJUDICATIVE SERVICES AND THE NEED FOR A TWO-TIER TRIAL SYSTEM IN CIVIL CASES
}

\author{
Albert W. Alschuler*
}

In the State of Nature there wants a known and indifferent Judge, with Authority to determine all differences according to the established Law. For every one in that state being both Judge and Executioner of the Law of Nature, Men being partial to themselves, Passion and Revenge is very apt to carry them too far, and with too much heat, in their own Cases.

John Locke 1

\section{INTRODUCTION: IMPARTIAL ADJUDICATION as an Instrument of PeAce}

\section{A. A Parable of the Subway}

\begin{abstract}
A T about 2:30 p.m. on January 26 , I98I, in a subway station in Manhattan, three youths attacked a man who was carrying electronics equipment worth between $\$ 800$ and $\$ 1000$. The victim attempted to escape by running up a stairway, but his attackers pursued him. They caught their victim, beat him, and shoved him into a plate glass window. Although the window did not break, a door handle hit the man in the chest, tearing some tissue and cartilage and causing considerable pain. The youths continued their beating until a police officer arrived. Then two of them fled. The third failed to notice the arrival of the officer and was apprehended while beating the victim.

Although only sixteen, the arrested youth was wise in the ways of the criminal justice system. He claimed that the man with the electronics equipment had attacked him and thereby provoked the incident. Because both the attacker and the victim had filed complaints, the victim soon received written notice of an informal hearing at which he could mediate his dispute with the mugger. The victim declined the opportunity.
\end{abstract}

* Professor of Law, University of Chicago. Harvard College, A.B., I962; Harvard Law School, LL.B., I965. I am grateful to Gerhard Casper, Jeffrey Chasnow, Richard A. Epstein, Daniel R. Fischel, William M. Landes, John H. Langbein, Bernard D. Meltzer, Geoffrey P. Miller, Richard A. Posner, Judith Resnik, Stephen J. Schulhofer, Steven Shavell, and Ann Woolhandler for valuable suggestions and to the Russell Baker Scholars Fund at the University of Chicago Law School for research support.

1 J. Locke, Two Treatises on Government 396 (Cambridge U. Press. ed. Ig6o). 
The youth was ultimately punished for his crime. Although he failed to appear in court on the return date specified in the summons, it was not long before he was arrested for a similar crime in Brooklyn. The two cases were consolidated, and after the defendant pleaded guilty to reduced charges, he served six months in jail. He later received a three-to-nine year penitentiary sentence for additional robberies committed after his release. At last word, he was still in prison.

The victim of the mugging, however, was never told what had happened to his attacker. He thought that the case had ended when he declined the offer of mediation. The victim decided that he needed a gun, and his gun became famous. The victim's name was Bernhard Goetz. ${ }^{2}$

\section{B. Subway Civics: Some Signals for Criminal and Civil Justice}

Goetz's use of his gun to wound four youths in a New York subway just before Christmas I 984 received public acclaim that subsided only when the full extent of his bloodlust became known. ${ }^{3}$ Goetz's unwillingness to rely on a legal system that had invited mediation with his attacker - as well as the public's initially favorable response to Goetz's act of violence - suggests what can befall a society whose legal system fails or is perceived to fail.

2 For fuller descriptions of these incidents, see McFadden, Goetz: A Private Man in a Public Debate, N.Y. Times, Jan. 6, 1985, at AI, col. I; Footnote to a Subway Shooting, N.Y. Times, Jan. 14, I985, at Ar8, col. I.

${ }^{3}$ On December 22, 1984 , four men approached Goetz while he was riding in a New York subway. According to police reports, the four, aged 18 and $I 9$, first asked Goetz for a match, then for the time, and finally for five dollars. Although no currently available evidence suggests that Goetz knew this fact, three of the men carried sharpened screwdrivers (devices that may be used to break into video-game cash boxes more frequently than they are used as weapons). All four had criminal records.

Goetz had a gun which he had acquired in Florida after the I98I mugging, his application for a firearms permit in New York having been rejected. Goetz opened fire, hitting all four men. He then fled into the subway tunnel. A few weeks later, he surrendered to police and was charged with attempted murder.

The shootings resulted in an initial groundswell of support for Goetz. As the New York Times reported, "People seem less concerned with the exact events . . than with the concept that someone somewhere had chosen to fight back." Fein, Angry Citizens in Many Cities Supporting Goetz, N.Y. Times, Jan. 7, 1985, at BI, col. I. A grand jury indicted Goetz only for a weapons violation.

One of the men was paralyzed by the shooting. Criticism of the grand jury escalated when it was disclosed that Goetz had looked at one of the youths on the floor of the subway car, said, "You don't look so bad, here's another," and then shot again. A new grand jury was convened. In March 1985, Goetz was indicted for attempted murder. In January 1986, however, a trial judge concluded that the grand jury had been improperly instructed on the issue of selfdefense and dismissed the attempted-murder indictment. The case may be submitted to a grand jury once again. See Step-by-Step: A Shooting, a Dismissal, N.Y. Times, Jan. I7, 1986, at $\mathrm{B}_{3}$, col.r. 
Although Goetz's act suggests a lesson about retribution and criminal justice, ${ }^{4}$ it also offers a broader lesson about procedure. Goetz's despair and indignation may not have been entirely the product of his sense that his attacker had gone unpunished. More fundamentally, Goetz may have concluded that no one in the legal system had been willing to listen and to determine whether this mugger deserved punishment. In place of a prompt hearing at which a judge or jury would decide what had happened, this system had offered a conciliation proceeding designed to encourage the victim and the victimizer to resolve their differences and go on their way. The apparent procedural default of a bureaucratized and overburdened legal system may have fueled Goetz's sense of injustice as much as his misperception of the substantive outcome.

The eruption of Goetz's anger underscored a Lockean lesson. Adequate adjudicative services are central to the maintenance of a civilized society. This lesson is not confined to criminal proceedings. The vindication of private rights, no less than punishment for wrongs against society, is an essential part of the sensed social compact. By assuring individuals that claims of injustice will be heard, considered, and judged on their merits, the judicial branch of government performs a distinctive service. More than other governmental agencies, courts reinforce a sense of individual worth and individual entitlement. The promise that every person's claims of injustice will be taken seriously tends to lessen alienation and to foster an awareness of community obligation. When it is alleged that one member of a community has wronged another, someone must be available to hear both sides and to provide an impartial, authoritative resolution of the dispute.

Adjudication is not a service that America provides very well. My earlier writings have focused on criminal cases, exploring the relationship between the complexity of America's trial procedures and its lopsided dependency on the guilty plea. ${ }^{5}$ Adjudication has become less accessible in civil cases as well. In response to growing caseloads

\footnotetext{
4 This act offers a reminder of a common social perception. When public retribution for wrongdoing is withheld, self-help and private vengeance become more likely. In the days when almost every justification for almost every policy was cast in terms of its pragmatic consequences, this observation supplied a common argument for recognizing retribution as an appropriate objective of the criminal law. See, e.g., R. Caldwell, Criminology 390-93 (1956); P. TAPPAN, Crime, Justice, ANd CoRrection 242 (I960).

5 Perhaps our criminal trial procedures are inherently unworkable, or perhaps we have failed to provide the resources needed to make them work. In either event, our legal system appears to have tried every solution except the obvious ones - simplifying our trial procedures or else providing the resources needed to make them available. We have embraced and extolled plea bargaining, diversion, supervision, pretrial probation, accelerated rehabilitative disposition, and mediation with muggers. See Alschuler, Implementing the Criminal Defendant's Right to Trial: Alternatives to the Plea Bargaining System, 50 U. CHI. L. REv. 93I (I983).
} 
and perceptions of administrative crisis, judges, lawyers, and legal scholars have embraced a host of nonadjudicative shortcuts. They have invented innumerable rationalizations for not doing the job and innumerable ways to avoid it.

This Article focuses on the failure of adjudicative services in civil cases. At the outset, it briefly considers the economics of litigation and reexamines some fundamental, frequently forgotten reasons for the provision and financing of these services by government. Then it turns to the settlement of civil lawsuits, exploring some ways in which the defects of America's legal system have distorted the settlement process and noting some reforms that could make settlements more just. It contends that deficiencies in judicial services have kept the amount of adjudication below the level that might have been expected in an era of vastly expanded rights.

The Article considers one prominent response to the shortcomings of American procedure - today's closer judicial supervision of discovery and other pretrial activities. It suggests that "managerial judging," although an important part of the solution, is also part of the problem. As presently structured, judicial supervision has made pretrial proceedings more complex without adequately controlling pretrial abuse. In addition, existing procedures do not sufficiently guard against the threat to impartiality that may arise from judicial "case management."

Finally, the Article reviews some practices in America and other nations that mark an appropriate path toward reform. It proposes a revised system of procedure that could cure or alleviate the defects noted earlier. In this system, current "pretrial" activity would be converted into a "first instance" trial that either party could treat as advisory if he were willing to risk the costs of a "second instance" proceeding.

\section{The Public Financing of Private Litigation}

For some economically minded legal scholars, impartial adjudication is just another service - like pressing clothes or hauling trash. These scholars suggest that the rationing of adjudication by queue is to be expected when the cost of obtaining this service is below its market-clearing price, ${ }^{7}$ and they consider whether it might be better to provide this service through a private market or, if not, at least to

6 See Resnik, Managerial Judges, 96 HaRv. L. Rev. 376 (1982).

'See Landes, An Economic Analysis of the Courts, I4 J.L. \& Econ. 6I, 74-77 (197I); Posner, An Economic Approach to Legal Procedure and Judicial Administration, 2 J. LegaL STUD. 399, 445-47 (1973). 
finance it primarily by collecting fees from people and organizations that use it. 8

Although litigation commonly proves expensive to the litigating parties, these parties pay only a fraction of the cost of operating the courts. In that sense, governments subsidize civil litigation, and the subsidy is substantial. For example, during fiscal year I982, the estimated cost to the federal government of a tort suit filed in a United States district court was $\$ \mathrm{I} 740$. In certain tort cases tried to juries, the average cost was $\$ 15,028.9$ Noting these expenses and, in addition, the fact that the federal government obtains only $\$ 60$ per case in filing fees, Richard Posner concluded, "[T]he subsidy is far too great." 10

Posner's recent study of The Federal Courts proposes "stiff user fees" as a means of reducing federal caseloads. ${ }^{11}$ Although Judge Posner stops short of urging that litigants bear all the expenses of their lawsuits, he recognizes only one valid reason for public payment of some of these expenses: "The fact that a lawsuit provides information that enables other disputants to settle their disputes without litigation means that the parties to the suit are conferring benefits on other people, and they ought to be able to shift some of the costs of the litigation to those beneficiaries."12

Judge Posner argues in the same volume that tribunals that fail to publish their decisions ordinarily do not provide much information of benefit to the community. The essential function of these tribunals is to resolve disputes about the past. ${ }^{13}$ Posner's analysis offers little reason for subsidizing litigation in these courts.

Even from an "efficiency" perspective, however, individuals should not bear all the expense of vindicating their rights, not even through proceedings that create only the most informal sorts of precedent. ${ }^{14}$

8 See, e.g., Landes \& Posner, Adjudication as a Private Good, 8 J. Legal StUd. 235 (r979).

9 J. Kakalik \& A. RobyN, Costs of The Civil Justice System: Court Expenditures For Processing TORT Cases xviii, xix (Rand Inst. for Civil Justice I982).

${ }^{10} \mathrm{R}$. POSNER, The Federal Courts: Crisis AND ReForm I32 (I985).

11 Id. at 13I-36. Increasing user fees in one set of courts for the purpose of channeling disputes into another set of courts presents different issues from raising these fees in order to discourage litigation in any court. Substantially increased filing fees in the federal courts might not be objectionable if state-court filing fees remained low and if areas of exclusive federal jurisdiction were exempt from filing-fee requirements. Judge Posner does not suggest either of these qualifications, however; and although he discusses and defends the fact that his proposal would route some cases from federal into state courts, he also discusses in general terms the justification for subsidizing private litigation. Posner's position is apparently that the current subsidy is excessive even apart from its "routing" effects. This Article accordingly treats the proposal as raising the question whether our legal system should seek to reduce caseloads generally through a cost-infliction strategy.

12 Id. at Io; see id. at $13 \mathrm{I}-32$.

13 See id. at 3-4.

14 To ensure an appropriate adversarial stake in litigation, it seems appropriate to require litigants either to pay part of the costs of litigation or else to run a risk that they will pay part HeinOnline -- 99 Harv. L. Rev. 1812 1985-1986 
Posner's analysis considers only the effects of subsidization within a dispute-resolution system. It ignores effects that go beyond dispute resolution to what might be called dispute prevention. Posner fails to consider how a reduction in public funding for the courts ultimately might affect conduct in marketplaces and on highways. Subsidized private litigation can benefit the public, not only by creating benchmarks that promote the settlement of disputes, but also by persuading potential wrongdoers that the violation of rights is likely to be unprofitable. ${ }^{15}$

This argument for subsidization probably seems clearest when the cost to private parties of vindicating their rights exceeds the value of these rights. When the cost of adjudication exceeds the amount at stake, ${ }^{16}$ people whose rights have been violated are likely to acquiesce in the violation or "lump it." As potential wrongdoers gain confidence that their potential victims will not seek legal redress, the economic disincentive to the violation of rights fades and disappears. In a world in which individuals seek only to maximize their wealth, any right whose economic value is less than the cost of its vindication is in jeopardy. 17

Of course, when the victim of a wrong fears its repetition, he may rationally accept a short-term loss and pay what is necessary to correct the wrong. This action may benefit the victim by persuading the wrongdoer that he will not be allowed to profit from improper conduct in the future. With sufficient assurance that the wrongdoer will desist or turn to a new victim, however, the initial victim is likely to yield rather than pursue this deterrent strategy.

Even when wrongdoers do not have continuing relationships with their victims, they have a continuing relationship with society. The subsidization of private litigation enables a society to pursue the same deterrent strategy that an individual who feared further victimization might pursue. This subsidization furthers a general perception that wrongdoing will prove unprofitable. ${ }^{18}$

of these costs if they lose. The argument that follows is not that litigation should be free or that litigants should be relieved of the expenses that they currently bear. It is only that, in a legal system that does not require losing litigants to bear their opponents' litigation expenses, substantial subsidization of the costs of private litigation is appropriate.

15 Because the public has an interest in discouraging unfounded lawsuits just as it has an interest in discouraging other harmful conduct, the argument for subsidization that follows applies not only to plaintiffs who are forced to go to court to vindicate their rights but also to defendants who must go to court to protect themselves against unjustified claims.

${ }^{16}$ Situations in which even the successful pursuit of legal remedies will be unprofitable are common in every society and especially common in a society like ours that has "professionalized" litigation and made the process prolonged and complicated.

17 I do not contend that governments should subsidize litigation so much that people turn routinely to the courts for the redress of every passing injury. "Lumping" trivial injuries and resorting to lawful means of self-help are sometimes marks of appropriate self-reliance.

18 This perception promotes efficiency when rights themselves are defined in a way that advances the efficient allagation of reseprifces.L. Rev. 1813 1985-1986 
This economic argument for subsidization is not limited to cases in which wronged parties are likely to "lump it" but rather extends to every lawsuit. Although Judge Posner maintains that most common law rules of liability are economically efficient, ${ }^{19}$ his discussion of judicial services neglects the fact that rules can be efficient only when they are enforced. For example, Posner argues that use of the familiar "Hand formula" 20 in negligence cases promotes efficient behavior. ${ }^{21}$ In our current legal system, however, the Hand formula is textbook law rather than law in action, and a substantial increase in filing fees would further diminish its ability to provide appropriate economic incentives.

Confronted by lengthy delays and other impediments to legal redress, an injured plaintiff with a just and provable claim for $\$ 10,000$ in damages may rationally settle for $\$ 5000$ or some other fraction of the amount that the Hand formula seems to promise him. Were our legal system to increase the costs of justice in the manner that Judge Posner suggests, the amount that the plaintiff would be likely to accept in settlement would grow smaller. Wrongdoers would be required to "internalize" a smaller portion of the cost that their conduct has inflicted on others. Their incentive to engage in improper or inefficient conduct would increase. ${ }^{22}$

In short, when justice is delayed, high-priced, or inaccessible, the de facto rule of liability in negligence cases is not the Hand formula. It is the amount that the Hand formula would award multiplied by a fraction, and every increase in the cost of purchasing justice makes the fraction smaller. At least in a legal system that does not shift the winning party's legal expenses to the losing party, the public interest

19 See R. Posner, Economic Analysis of Law 25-192 (2d ed. 1977).

${ }^{20}$ See United States v. Carroll Towing Co., 159 F.2d 169, I73 (2d Cir. 1947) (L. Hand, J.) (imposing liability when the cost of avoiding injury would have been less than the cost of the injury multiplied by its anticipated probability).

${ }^{21}$ See Posner, A Theory of Negligence, I J. Legal Stud. 29 (1972).

${ }^{2}$ Cf. San Diego Bldg. Trades Council v. Garmon, 359 U.S. 236, 247 (1959) ("The obligation to pay compensation can be, indeed is designed to be, a potent method of governing conduct and controlling policy.").

Litigation expenses that are borne equally by both parties may not alter the incentives that substantive liability rules appear to provide. For example, just as the high cost to a plaintiff of hiring a lawyer may make it rational for this plaintiff to accept in settlement a smaller amount than the Hand formula seems to promise, the high cost to a defendant of hiring a lawyer may make it rational for him to pay more. When opposing parties are equally wealthy and when litigation costs are symmetrical, settlement is likely to approximate the result that substantive liability rules would dictate. Nevertheless, in cases in which employees sue their employers and in many other situations, opposing parties are not likely to be equally wealthy, and some costs - for example, the burdens of delay (see infra pp. 1822-24) - are distributed in an almost entirely one-sided fashion. Stiff filing fees of the sort proposed by Judge Posner would be borne by federal court plaintiffs. These fees would, dollar-for-dollar, undercut the Hand formula and other substantive rules of liability. 
in discouraging wrongful conduct justifies the subsidization of litigation. (Although the issue is more problematic, subsidization may be efficient in a cost-shifting system as well). ${ }^{23}$

Not all law-and-economics scholars have taken so narrow a view of the adjudicative process as Judge Posner. Most notably, the work of Steven Shavell has recognized that private litigation serves general deterrent purposes. ${ }^{24}$ Like Judge Posner and other economic analysts, however, Professor Shavell appears to have overlooked another reason for subsidization - the Lockean lesson of Goetz's gun. In the absence of an effective peaceful means of vindicating private rights, people retain a plausible claim that they are entitled to vindicate these rights through self-help. A society that wishes its members to renounce this claim must make a peaceful means of adjudicating disputes available to them. ${ }^{25}$ By assuming that the alternative to private adjudication is simply the lack of this service ("lumping it" rather than justifiable self-protection), economists have leaped over a critical stage of analysis. ${ }^{26}$ Moreover, when the time necessary to obtain a trial is mea-

23 In theory, an unsubsidized, cost-shifting system requires a wrongdoer to bear all the costs that his conduct has inflicted on others (both the costs inflicted on private individuals and those imposed on the government). From a deterrent perspective, this unsubsidized, cost-shifting system might seem obviously superior to either a non-cost-shifting or a subsidized system. Either of these systems would relieve a wrongdoer of some of the costs of his wrongdoing. The difficulty is that both cost shifting and the absence of public subsidization make litigation more risky, not just for one party, but for both.

Typically, the outcome of a lawsuit cannot be foreseen, and an unsubsidized, cost-shifting system requires each party to assume a substantial risk that he will bear all the expenses of a suit. When people are risk-averse, they may be more reluctant to resort to adjudication in a cost-shifting system than in one in which each party pays a share of the total costs. See Shavell, Suit, Settlement, and Trial: A Theoretical Analysis Under Alternative Methods for the Allocation of Legal Costs, I I J. LEGAL STUD. 55, 62 (1982). In both cost-shifting and non-cost-shifting systems, wronged parties are unlikely to attach significant value to the general societal interest in deterring future misconduct when they calculate the potential gains and potential losses of pursuing their legal remedies. For this reason, litigation may fall below its "optimal" level in either system unless it is substantially subsidized.

To put this possibly counterintuitive argument another way, a system in which adjudication is viewed as "free" or "not too expensive" may be more effective in deterring misconduct than a system in which wrongdoers face more severe sanctions but in which litigation is seen as so risky that people hesitate to call wrongdoers to task.

In determining what contribution each of the three principal sources of litigation financing - the government, the prevailing party, and the losing party - should make, a variety of combinations and principles seem plausible. Most of the economic literature has focused only on how privately incurred costs should be allocated between the two litigants. The remainder has considered how costs should be allocated between private litigants and the government. No economic study of which I am aware has addressed the optimal contribution of all three sources.

${ }^{24}$ See Shavell, The Social Versus The Private Incentive to Bring Suit in a Costly Legal System, II J. LEGAL STUD. 333 (1982).

${ }^{25}$ This argument for subsidization extends not only to the indigent but also to people for whom vindicating their rights through self-help would be less costly than vindicating these rights through the more peaceful methods that society has required.

${ }^{26}$ Like subsidization, a cost-shifting, "loser pays" rule can ensure a peaceful means of 
sured in years, the assertion of a moral right to self-help remains plausible despite the subsidization of adjudication.

To assert that justice must be rationed by queue unless it is rationed by price is erroneous. Although the government has priced emergency firefighting services substantially below cost, these services have not been rationed by queue to any great extent. People might be surprised to find this situation changed: "Thank you for calling 9II. If your house is still burning in April I987, a fire engine will come." Apart from the fact that they gradually have gotten used to it, Americans also might be shocked to discover that justice has been rationed both by price and by queue to the extent that it often is effectively unavailable.

In summary, the subsidization of private litigation can have at least three valuable consequences. It can create precedents that aid the settlement of disputes (an interest recognized by Judge Posner); it can discourage wrongful primary conduct (an interest neglected by Posner but recognized by Professor Shavell); and it can discourage violent self-help (an interest neglected by Posner and Shavell but recognized by John Locke). No list of consequences, however, can capture fully the reasons for the public provision of adjudication. In the end, some rights are sensed as rights, not merely as ecoromically efficient arrangements. That rights imply remedies is not a fresh or transient idea. ${ }^{27}$ When adjudication is unavailable, a lumberjack may respond to an invasion of his rights with his fists. Nevertheless, society's obligation to provide adjudication to an elderly invalid who cannot fight is as strong as or stronger than its obligation to provide adjudication to a lumberjack. The provision of adjudication is the means by which society keeps the promises of its substantive law and assures both lumberjacks and invalids that their rights are taken seriously.

Impartial adjudication is one of the first tasks of government. Indeed, a market that distributes other goods and services through

vindicating private rights and can make a wronged party's resort to the courts less expensive than self-help. An adjudicative system without either cost shifting or subsidization, however, could lead to frequent resort to extra-judicial remedies (as well as to frequent "lumping it" or acquiescence in the violation of rights). It is probably no accident that English cost-shifting rules emerged at a time when officials were selling judicial services at a profit. Without cost shifting, the high price of English justice might have led wronged parties to bypass the courts (just as it might have emboldened wrongdoers in their initial violation of rights). See infra note 96.

American colonists did not import the English system of exhorbitant fee exaction and profiteering from the sale of justice. The lower price of American justice may have made possible the development of the non-cost-shifting "American rule." See Leubsdorf, Toward a History of the American Rule on Attomey Fee Recovery, LAw \& CONTEMP. ProBs., Winter I 984 , at $9,12-13$.

${ }^{27}$ See 3 W. BLACKSTONE, COMmEnTARIES $*_{23}$ ("II]t is a general and indisputable rule, that where there is a legal right, there is also a legal remedy . . . ."). 
voluntary private contracts is premised on the availability of this service. As this basic service has become less accessible, however, observers have begun to alibi its absence. Like foxes who conclude that unreachable grapes are probably sour, some advocates of "alternative dispute resolution" seem never to refer to adjudication without adding a disparaging modifier like "full-blown." Nevertheless, adjudication is not a dirty word. It is a cornerstone of commerce, an essential social service, and a hallmark of civilization.

\section{EXPLODING THE LITIGATION EXPLOSION}

Scholars and judges commonly proclaim that America is experiencing a litigation explosion. ${ }^{28}$ Indeed, Chief Justice Burger recently claimed that "mass neurosis . . . leads people to think courts were created to solve all the problems of society."29 The number of lawsuits filed in American courts (especially the federal courts) has increased dramatically, and burgeoning caseloads (measured in terms of the number of lawsuits filed or terminated, not the number of trials) have led to a widespread sense of crisis. ${ }^{30}$

Nevertheless, in a nation in which trial and pretrial procedures are unusually expensive, ${ }^{31}$ in which litigation is unusually risky, ${ }^{32}$ in which delays are long, ${ }^{33}$ and in which the first goal of many judges is to avoid judging, ${ }^{34}$ Americans have not rushed to the courts in unusual numbers. As Mark Galanter has demonstrated, civil lawsuits are much less frequent in twentieth-century America than they have been in many other societies (including colonial America where, in some places, litigation rates appear to have been more than four times ours). ${ }^{35}$ Current litigation rates in the United States are only slightly

2s The development of today's "litigation explosion" literature is described in Galanter, Reading the Landscape of Disputes: What We Know and Don't Know (And Think We Know) About Our Allegedly Contentious and Litigious Society, 3I UCLA L. REV. 4, 5-1 I (1983).

29 N.Y. Times, Aug. 22, 1985, at A21, col. I.

30 For an examination of the caseload crisis and its ill effect on the federal courts, see $\mathbf{R}$. POSNER, supra note Io. In state courts, civil filings apparently increased $14 \%$ during the three years prior to $198 \mathrm{x}$ but declined $4 \%$ in the three years after. See Elsasser, Furor Over Lawsuits May Overstate Case, Chicago Tribune, Apr. 27, 1986, \$ I, at 3, col. 5.

31 See infra pp. 1824-25, 1832-36.

32 See infra pp. $1825-28$.

${ }^{33}$ See infra pp. 1822-24.

${ }^{34}$ See infra pp. $1828-30$.

35 Galanter, supra note 28 , at $40-4 \mathrm{I}, 56-57$. The litigation rates noted by Galanter are filing rates, not trial rates. Because the proportion of cases resolved by trial has declined dramatically, the disparity in trial rates undoubtedly would be substantially greater.

Galanter and his critics sometimes appear to have spoken at cross-purposes. The claim that there is a "crisis in the courts" is not in tension with Galanter's demonstration that Americans are not unusually litigious. Our cumbersome adjudicative machinery may be incapable of meeting a demand for legal services that, judged from either a historical or a comparative 
higher than those in England, France, and Denmark. They are somewhat lower than current rates in Australia, Canada, and New Zealand. ${ }^{36}$ The crisis in our courts that observers decry may be the product of an inadequate supply of adjudication rather than of the excessive litigiousness of our society.

Although, when viewed from a long-term perspective, there may have been no significant litigation explosion, there has been a law explosion. Indeed, one suspects that some of those who have decried the litigation explosion have simply misspoken. Their ill-articulated complaint has not been about the volume of litigation but rather the expanding reach of our substantive law. ${ }^{37}$

The law explosion of recent decades seems unmistakable. In I945, the Illinois Revised Statutes were contained in a single volume. In I955, there were two volumes; in I965, three; in I975, four; and in r985, five. ${ }^{38}$ Perhaps some of the new laws contained in these volumes have reduced the amount of litigation by simplifying earlier complexities and by establishing new agencies to relieve the workload of the courts. It seems a reasonable guess, however, that many more of the new statutes have tended to increase the volume of litigation. ${ }^{39}$ Certainly the growth of judge-made law would have been expected to increase the flow of lawsuits. This law has greatly expanded the scope of rights against the government and against the manufacturers of injury-producing products. ${ }^{40}$ Lawsuits are one obvious method of vindicating new rights, yet the current "ratio" of adjudication to substantive rights appears low. In addition, an enormous growth in the number of lawyers (from 286,000 in 1960 to 650,000 in 1985$)^{41}$ might

perspective, is not exceptionally high. But cf. R. PoSNer, supra note 10, at $76-77$ (criticizing Galanter on the ground that his analysis "does not show the growth of the federal caseload since 1960 is not something to be concerned about").

${ }^{36}$ See Galanter, supra note 28, at 52-54 table 3. Although American litigation rates are no higher than those of some other countries, litigation is substantially more frequent in the United States than in Spain, the Netherlands, Italy, and Japan. See id.; see also infra note 54 (discussing reasons for the low litigation rate in Japan).

${ }^{37}$ Unlike Galanter, who appears reassured by the lack of a more significant litigation explosion, I believe that a few litigation bursts might be in order. Our legal system should accommodate these bursts (and relieve its current crisis) by simplifying its principal form of trial and making adjudication more accessible.

38 See Ill. Rev. Stat. (1945); Ill. Rev. Stat. (I955); Ill. Rev. Stat. (I965); Ill. Rev. StaT. (1975); Ill. REV. STAT. (I985).

${ }^{39}$ Arthur R. Miller has noted a similar proliferation of federal legislation:

Throughout the I960's and I970's Congress seemed to be operating a "new-right-ofthe-month club." . . The same societal forces that fueled the civil rights movement ... impelled Congress to respond to other demands for justice, and new statutory rights of action became available in the environmental, consumer, political rights, and safety fields.

Miller, The Adversary System: Dinosaur or Phoenix, 69 MINN. L. REv. I, 5 (Ig84).

40 See W. Keeton, D. Dobbs, R. Keeton \& D. Owen, Prosser and Keeton on the LAW OF TORTS $\$ \$ 97-98$, I3I (5th ed. I984).

41 The figure for Ig60 appears in B. Curran, The Lawyers Statistical Report 4 (Am. 
have been expected to increase the volume of litigation, and so might the increased provision of legal services to the poor. ${ }^{42}$ So, too, might the legalization of advertising by lawyers, ${ }^{43}$ the relaxation of various rules against encouraging litigation, ${ }^{44}$ the invalidation of minimumfee schedules, ${ }^{45}$ the judicial implication of private causes of action from regulatory provisions, ${ }^{46}$ and the enactment of scores of statutes that authorize the award of attorneys' fees to victorious plaintiffs (frequently from government funds). ${ }^{47}$ Why has a more dramatic litigation explosion not materialized?

Professor Galanter's study supplies part of the answer. To some extent, a reduction in the amount of contract and property litigation has made room for title VII suits, product liability suits, medical malpractice suits, and the like. ${ }^{48}$ Perhaps the reduction of commercial litigation has been partly the product of a diminution in commercial disputes. The form contracts of large business entities may provide for contingencies that the draftsmen of individually negotiated contracts overlooked. At the same time, the partial eclipse of contract litigation also must reflect the growth of commercial arbitration. People who are able to escape our burdensome judicial procedures commonly do so. ${ }^{49}$

Moreover, as Professor Galanter recognizes, there has indeed been a litigation explosion if one looks only to the most recent twenty-year period and to filings rather than to trials. Between 1960 and I 980 , federal court filings per capita nearly doubled. ${ }^{50}$ This increase, however, did not yield a remotely comparable increase in the number of trials. Instead, during the same period, the percentage of federal cases terminated during or after trial fell from 10.3 to 6.5 .51 "Similarly,"

Bar Found. 1985). The figure for 1985 was reported by Barbara A. Curran, Project Director, American Bar Foundation, in a telephone interview on April 8, 1986, and will be published in a I986 supplement to The Lawyers Statistical Report.

42 See Weinstein, The Poor's Right to Equal Access to the Courts, I3 CoNN. L. Rev. 65I, 659 (I981).

${ }_{43}$ See Bates v. State Bar, 433 U.S. 350 (1977).

4 See Miller, supra note 39 , at 4-5.

45 See Goldfarb v. Virginia State Bar, 42 I U.S. 773 (1975).

${ }^{46}$ See, e.g., J.I. Case Co. v. Borak, 377 U.S. 426 (1964).

${ }^{47}$ See Percival \& Miller, The Role of Attorney Fee Shifting in Public Interest Litigation, LaW \& Contemp. Probs., Winter 1984, at 233, 233.

48 See Galanter, supra note 28 , at 42.

49 The parties to a commercial transaction are more able than other prospective litigants to plan for arbitration. One cannot negotiate today with people who might run one down in an automobile tomorrow, and once a dispute arises, the interests of one side or the other are likely to make it too late to reach an agreement to arbitrate.

so See Galanter, supra note 28 , at 37 . In absolute numbers, federal court filings have more than tripled since 1960 . See R. POSNER, supra note 10 , at 63 .

51 See Galanter, supra note 28 , at 44 table 2. During the previous 20-year period, the percentage of civil cases terminated during or after trial had fallen from 15.2 to 10.3. See id. 
Professor Galanter notes, "from the early I960's to I980 - a period of increased filings ... . - the number of jury trials actually held fell in both Cook County and San Francisco County." 252 Professor Galanter notes similar findings in several other state court jurisdictions and concludes: "The portion of cases that run the whole course has declined. But for the minority of matters that run the full course, adjudication is more protracted, more elaborate, more exhaustive, and more expensive." 53

The causal relationship between Galanter's second observation and his first seems apparent. Our society has made adjudication more expensive and less available. Recent years have seen both an expansion of law and a diminishing opportunity to invoke it. Perhaps, in fact, overly elaborate procedures have saved us from overly expansive law. At the same time, these procedures have limited our access to justice. ${ }^{54}$

\section{The Failure of Adjudication and Its Effect on Civil SetTlement}

Americans may not litigate enough, especially if litigating means more than filing suit. Just as they bargain too much for guilty pleas, they may settle too many civil cases. I do not contend that there is any "correct" number of negotiated settlements, nor would I be distressed if amicable parties settled every potential lawsuit on terms that they considered fair. Nevertheless, Americans currently settle many of their disputes for the wrong reasons. Adjudication would provide a fairer way of resolving some of these disputes.

52 Id. at $43-44$ (citation omitted).

53 Id. at 44 .

54 Although Galanter seems to treat the lack of a genuine litigation explosion in America as reassuring, his discussion of litigation in Japan recognizes that a lack of litigation may be a legitimate cause for concern. Chief Justice Burger and others had portrayed Japan, in Galanter's words, "as a peaceful garden . . . uncorrupted by the worm of litigation." Galanter, supra note 28, at 57. Galanter suggests, however, that Japan's unusually low rate of litigation is the result not of a lack of demand for litigation but of a restriction of supply.

In Japan, the number of lawyers eligible to appear in court has deliberately been kept low. No more than about 500 law graduates can enter the private barristry, the corps of career prosecutors, and the judicial corps in a single year. The number of judges has been kept low as well. The number of judges per capita in 1969 was less than $40 \%$ of what it had been 79 years earlier. Finally, Japan imposes procedural hurdles to litigation, notably a requirement of prior participation in conciliation proceedings. Id. at 57-59.

What is true of Japan also seems true of America, albeit on a less dramatic scale. Gálanter's study probably tells us less about the character of our allegedly contentious and litigious society than it does about our government's failure to afford workable mechanisms for resolving our disputes. We, too, have restricted our supply of adjudicative services. America, however, has not done it by limiting its corps of lawyers. 
Although many people favor prohibiting plea bargaining in criminal cases (I among them), ${ }^{55} \mathrm{I}$ know of no one who objects in principle to the settlement of civil lawsuits. Despite the significant ways in which private litigation benefits the public, the parties to civil litigation are not charged with the responsibility of allocating blame. For the most part, these parties allocate instrumental goods (like money) among themselves, and they may do so as they like. These parties may impose liability where the law would deny it and deny it where the law would impose it. ${ }^{56}$ So long as civil settlement represents a reasonably knowing, reasonably voluntary allocation of resources by the parties most affected by this allocation, it is preferable to litigation. ${ }^{57}$

To suppose that civil settlement is always admirable or at least unobjectionable, however, is mistaken. At an operational level, the settlement process can work unfairly in civil cases just as it can in criminal cases. This Article will note five sources of unfairness that currently infect the settlement of civil lawsuits. ${ }^{58}$ Together they reveal

5s See Alschuler, The Changing Plea Bargaining Debate, 69 Cilif. L. Rev. 652 (1981).

56 A procedure that declares a criminal defendant half-guiliy seems inconsistent with our traditional requirement of proof beyond a reasonable doubt. See id. at 703-07. Nevertheless, when the parties to a civil dispute choose to treat a defendant as half-liable (or doubly liable), no third party has reason to complain. So long as this choice is made knowingly, the decision to settle on the basis of extra-legal norms seems no more offensive than a decision by one party to make a gift and by the other to accept it. For evidence that private concepts of justice strongly influence the settlement process, see Eisenberg, Private Ordering Through Negotiation: Dispute-Settlement and Rulemaking, 89 HARv. L. REv. 637 (1976). In the absence of tangible third-party effects or a demonstration that "public values" are preferable to the values of the parties primarily affected by a settlement, protesting that private settlement may not permit the articulation and development of public norms seems largely beside the point. But see Fiss, Against Settlement, 93 YALE L.J. 1073 (1984).

${ }^{57}$ But see Fiss, supra note 56, at 1073-75. Although Professor Fiss claims that Americans settle too many civil cases, his reservations about settlement have little in common with mine. Fiss emphasizes that civil litigation sometimes involves more than an allocation of goods among disputing parties. He describes private settlement as "the civil analogue of plea bargaining." Id. at 1075. Certainly some civil actions - actions for treble damages, for example - do have punitive objectives. Nevetheless, the existence of "mixed objective" proceedings should not blur the different principles that ought to govern civil and criminal cases. These "mixed objective" proceedings do not provide a sound reason for collapsing the civil and criminal models into one.

"What distinguishes a criminal from a civil sanction and all that distinguishes it . . is the judgment of community condemnation which accompanies and justifies its imposition." Hart, The Aims of Criminal Law, LAW \& CONTEMP. ProBs., Winter 1958, at 401, 404. So long as a system of civil adjudication is fair, public objectives may be served by private litigation even when the parties compromise. And even when public objectives are not fully served, to attempt to force unwilling private parties to champion these interests is likely to prove ineffective. Criminal cases differ from civil cases, not primarily because they involve public interests, but because their principal object is to determine whether defendants merit punishment. "The ... administration of a system of reward or penalty depends upon an objective determination of whether the reward or penalty is deserved." Alschuler, supra note 55, at 705 (footnote omitted).

58 This list is not exhaustive. Another potential source of unfairness in civil settlement, for 
how the defects of America's adjudicative system have distorted the settlement process. They are: first, the quantitative inadequacy of our adjudicative services; second (a closely related phenomenon), the complexity of our trial and pretrial procedures; third, the substantive uncertainty created by our inadequately law-bound system of jury trials; fourth, the exertion of direct judicial pressure to settle; and fifth, the ability of disputants to encourage settlement by driving up their opponents' costs.

\section{A. The Quantitative Inadequacy of Adjudicative Services}

A clear manifestation of the current shortage of adjudicative services is the length of courthouse queues throughout America. Delays of months and years before trial no longer seem astonishing. In the Los Angeles Superior Court, the median time between the filing and trial of a civil action was 4.5 months in 1942 . This period doubled to 9 months in 1952 , more than doubled to I9 months in I962, grew to 30 months in 1972 , and increased again to $4 \mathrm{I} .5$ months in $1982 .{ }^{59}$ Although the delay encountered in large cities like Los Angeles ${ }^{60}$ is atypical, a waiting period of two and one-half years between the filing of a lawsuit and its disposition by jury trial now appears routine even in small city jurisdictions. ${ }^{61}$

example - one that merits more empirical study than it has received - is inadequate representation by lawyers.

59 M. Selvin \& P. Ebener, Managing the Unmanageable: A History of Civil Delay IN THe Los ANgeles Superior Court 27 table 2. I (Rand Inst. for Civil Justice 1984).

${ }^{60}$ The clerk's office of the Circuit Court of Cook County, Illinois, estimates that a lawsuit filed in that court today will come to trial in just under three years. Telephone interview (Apr. 24, I985). As bad as things are in Chicago, they may be worse in New York. The New York Times recently described a case in which a plaintiff alleged that she had been discharged from her job in violation of a contract. Partly as a result of a system of frequent rotations in judicial assignments, the case had come before Io state-court judges over the course of four years. It still had not reached trial. The Times said that it could have reported cases that had been longer delayed and that had come before more judges; it sought, however, to describe a case that had been "typical in its passage through the system." Roberts, Case 1439/81: Days in Court Without End, N.Y. Times, Apr. 28, 1985, § IV, at 6, col. 2.

${ }^{61}$ The National Center for State Courts recently reported the median time from the filing of a civil lawsuit to the commencement of a jury trial in twelve jurisdictions. The jurisdictions were not randomly chosen; some were selected because they had "undertaken ... significant delay reduction effort[s] within the past 5-8 years." B. MaHONEy, L. Sipes \& J. ITO, IMPLEmenting Delay Reduction and Delay Prevention Programs in URban Trial Courts: Preliminary Findings from CuRRent Research (Nat'l Center for State Courts i985). The "fastest" of the jurisdictions studied was Jersey City, New Jersey, where the median time between the filing of a civil lawsuit and the commencement of a jury trial was about sixteen months. The "slowest" of the jurisdictions was Providence, Rhode Island, where the median period of pretrial delay was over four years. The median time for all twelve jurisdictions appeared to be about two and one-half years. See id. at 8 table II.I. In the federal courts, the median period between the filing of a civil suit and its disposition by trial was Ig months in I984. Because this figure includes disposition by nonjury trials, it does not indicate the period that a federal 
The pervasive assumption that the settlement of disputes is desirable appears to have made some observers indifferent to the leverage that produces settlement. Richard Posner, for example, once wrote:

To most experts in judicial administration, delay between the filing and final disposition of a legal claim is an unmitigated evil and the proper focus of judicial reform. This is an odd way to look at the matter ....

Delay is [sometimes] a source of benefits ... . It may increase the settlement rate. ${ }^{62}$

To the extent that delay produces settlements, however, it does so unfairly. Increased pressure for settlement ought to be regarded as a cost rather than a benefit of the queue. By enabling defendants to postpone the day of reckoning, rationing by queue systematically disadvantages plaintiffs; preserving the status quo favors the defendant in almost every lawsuit. ${ }^{63}$ Indeed, for a plaintiff without capital reserves or for an injured plaintiff whose medical bills are mounting, the inability of our society to deliver adjudicative services within a reasonable period of time may exert enormous pressure for compromise. ${ }^{64}$ A partial corrective for this injustice lies in revision of the common law rule that forbids the award of prejudgment interest on nonliquidated damages. ${ }^{65}$ When defendants do pay, they ought to discover that delay has gained them only a temporary advantage. ${ }^{66}$

court litigant was required to wait for a trial when his opponent wished to delay. See ADm. Office of the U.S. Courts, 1984 ANNuAl Report of the Director 290 table C6A.

62 Posner, supra note 7 , at $445-46$ (footnotes omitted). Of course Posner did not contend that delay is an unmitigated good. His study listed a number of costs as well as a number of benefits of delay.

${ }^{63}$ Very occasionally delay may benefit a plaintiff - for example, in a toxic tort suit in which the extent of the injury may not be known until some time after the suit has been filed.

${ }_{64}$ Queueing also creates pressure for "lumping it" and, in some cases, for self-help. A mandatory delay of 50 years between filing and trial probably would not increase settlement rates. Instead, it probably would reduce these rates substantially. From a purely economic perspective, an infinite queue would leave a defendant with no reason to settle (apart, that is, from the prospect that the plaintiff would throw a rock through his window or otherwise resort to self-help). Similarly, it would leave a potential plaintiff with no reason to file.

Scholars have emphasized the influence of anticipated trial outcomes on civil settlements, describing the settlement process as "bargaining in the shadow of the law." See, e.g., Mnookin \& Kornhauser, Bargaining in the Shadow of the Law: The Case of Divorce, 88 YALE L.J. 950 (I979). Frequently, however, Americans bargain in the shadow of unavailable law.

65 This rule has in fact been altered in various sorts of actions in a number of jurisdictions. See Note, Interest in Judgments Against the Federal Government: The Need for Full Compensation, 91 YALE L.J. 297, 302 nn.29 \& 32 (I98I).

66 Posner recognized that "delay ... increases error costs by widening the gap between damages and judgments that is created by the fact that . . . interest is usually allowed . . only from the date of judgment." Posner, supra note 7, at 446 . Oddly, although Posner objected to the economic distortion worked by the denial of prejudgment interest, he listed the settlement that this distortion encourages as one of the benefits of delay. See id. at $420-21$. Of course 
In some jurisdictions, courthouse queues are no more lengthy today than they were a generation ago. ${ }^{67}$ Nevertheless, this circumstance offers little reason to conclude that the underlying problem - the inadequate supply of adjudication - has stabilized even in these jurisdictions. William M. Landes noted in I97 I that queues are likely to "reach an equilibrium size because . . . trial demand is a decreasing function of waiting or queueing time."68 Despite vastly increased judicial expenditures, ${ }^{69}$ our multi-year queues remain, and increased settlement rates $^{70}$ may suggest that seemingly stable queues mask a growing problem.

\section{B. Procedural Complexity}

One cause of today's queues is the complexity of American trial procedures. ${ }^{71}$ This complexity has been produced in part by the controls believed necessary to make our jury system effective. In earlier writings on criminal justice, I noted some familiar features of the American jury trial, which, during this century, has become one of the most cumbersome and expensive fact-finding mechanisms that humankind has devised. These features include our prolonged, insulting, privacy-invading jury selection process; our wrangling over evidentiary issues; our frequently repetitive (as well as pointless and degrading) cross-examination by lawyers; and our formulation and delivery of jury instructions that, all the empirical studies tell us, jurors frequently fail to understand. ${ }^{72}$ Of course America's complex procedures not only contribute to the rationing of justice by queue; they also increase more directly the dollar cost of obtaining justice, notably by increasing the amount that litigants must spend on attor-

the payment of prejudgment interest cannot fully remedy the injustice wrought by pretrial delay. An award of interest is unlikely to be worth much to a plaintiff who has died prior to trial.

${ }^{67}$ See, e.g., R. PosNer, supra note ro, at 95.

68 Landes, supra note 7, at 75 .

${ }^{69}$ See R. POSNER, supra note 10, at 27 table 2.1 (in constant 1984 dollars, the federal court budget increased from $\$ 50$ million in 1960 to $\$ 925$ million in 1984); BUREAU OF JUSTICE Statistics, U.S. Def'T of Justice, Sourcebook of Criminal Statistics - 1983, at 20 table I.4 ( 1984 ) (state judicial budgets increased from $\$ 327$ million in $197 \mathrm{I}$ to $\$ 1.328$ billion in 1979, a $306 \%$ increase).

${ }_{70}$ See supra pp. I8I9-20. Our seemingly stable queues probably also have been purchased by an increase in "lumping it." See supra pp. I8I7-20.

71 This Article will indicate the cumbersome character of American pretrial procedures in its discussion of "managerial judging," a development that has corrected some pretrial abuses and aggravated others. See infra pp. $1832-36$.

72 See Alschuler, supra note 5 , at 99I-93, 999-1002, 1016-22. I recognize that a simple listing and characterization of these features of the American jury trial may be more provocative than enlightening, but this Article is not the place to develop (or even repeat) my earlier critique of American trial procedure. On the inability of jurors to understand jury instructions, see $R$. Hastie, S. Penrod \& N. Pennington, Inside the Jury 80, 23 I ( 1983 ) and Alschuler, supra note 5 , at $99 \mathrm{I}$ n.286. 
neys' fees. In civil as in criminal cases, procedural safeguards backfire when those whom the safeguards are intended to benefit find them too burdensome to use. ${ }^{73}$

Customary American trial procedures are plainly unworkable in small-stakes cases - a fact recognized, albeit inadequately, ${ }^{74}$ by the creation of small-claims courts. In large-stakes cases, many litigants probably can afford to pay for adjudication, but the product that they buy is archaic. Juries, which under traditional (but fortunately crumbling) rules are forbidden to take notes, ${ }^{75}$ resolve lengthy antitrust cases in which the evidence is so extraordinarily complicated that lawyers on both sides must have computers at their counsel tables to keep track of it. Indeed, if the truth be told, American trial procedures are not very serviceable for mid-stakes cases either.

The principal finding of the University of Wisconsin's Civil Litigation Research Project was that, despite our burdensome procedures, litigation pays. In particular, plaintiffs in the cases studied by the Project usually recovered more than they spent on costs and legal fees. ${ }^{76}$ Nevertheless, a similar finding probably would emerge from the study of any legal system, however costly and defective the system might be. People are unlikely to invoke legal procedures when these procedures will not benefit them. When the most reassuring thing that researchers can tell us about our adjudicative system is that it does not fool most of the people most of the time, that system appears to be in trouble.

\section{Substantive Uncertainty}

Although courthouse queues systematically benefit defendants, the lawlessness of our jury system - especially the largely unguided discretion that juries exercise in assessing damages - exerts pressure for settlement on risk-averse litigants on both sides. This pressure is likely to be intense for a seriously disabled plaintiff who fears a second tragedy if he leaves the courthouse empty-handed; but, in the aggregate, the uncertainties of our jury system may exert more pressure on defendants than on plaintiffs (even when the defendants are institutional litigants who, to some extent, can "spread the risk" over a number of cases). Capricious jury awards are probably more likely to benefit injured plaintiffs than to harm them, and there are only

${ }^{73}$ See M. Feeley, The Process is the Punishment (I979).

74 Legal fees of $\$ 100$ per hour can quickly take the joy out of a $\$ 1000, \$ 2500$ or $\$ 5000$ lawsuit, yet the pro se branch of the small claims court in Cook County, Illinois, hears no case in which more than $\$ 500$ is at issue. ILL. ANN. STAT. ch. IrOA, \$ 28I (Smith-Hurd I985), Historical and Practice Notes, at 6ri (1985).

75 See Silas, Write It Down?: Jurors' Note-Taking Debated, A.B.A. J., Apr. 1984, at 35.

${ }^{76}$ See Trubek, Sarat, Felstiner, Kritzer \& Grossman, The Costs of Ordinary Litigation, $3 \mathrm{I}$ UCLA L. REv. 72, 109-2I (1983). 
vague upper limits on punitive awards and awards for pain and suffering.

The perils of uncertainty appear to have intensified in recent years. Measured in constant dollars, most damage awards in San Francisco, California, and Cook County, Illinois, were no greater in the late I970s than they had been in the early I96os. Nevertheless, there was a striking increase in the number and size of very large awards. ${ }^{77}$ When litigation becomes a high-stakes lottery, many may seek to avoid the risk of playing.

A partial remedy for this source of unfairness in the settlement process seems apparent. About fifteen years ago, study commissions, judges, academics, prosecutors, police officers, prisoners' unions, and other reformers of widely disparate political viewpoints united to decry lawlessness in criminal sentencing. The result was a sudden and dramatic revolution in the sentencing process. The federal government and more than twenty states enacted major reforms; judges and parole boards established sentencing guidelines; and sentencing commissions were created by the federal government and many states. ${ }^{78}$ Lawless damage awards, the civil analogue of America's lawless criminal sentences of fifteen years ago, might be addressed in much the same way - through the establishment of "damages commissions" and "damages guidelines." Jurors could then receive at least as much guidance in awarding damages as they currently receive in determining liability. ${ }^{79}$

Greater certainty in the award of damages would have virtues apart from its effect on settlement negotiations. Most of the vices of excessive discretion identified in the judicial imposition of sentences exist to some degree in the award of damages by juries (although these vices have not been nearly so well documented). Some of these vices may, in fact, be aggravated by the inability of jurors to view a number of cases over time, to consult with others engaged in similar

77 M. Shanley \& M. Peterson, Comparative Justice: Civil Jury Verdicts in San Francisco aND COOK Counties, I959-I980, at xii-xiii, 26-30 (Rand Inst. for Civil Justice 1983). Although, measured in constant dollars, the amount of the average jury award nearly tripled in San Francisco, almost all of this increase was attributable to increases in large awards rather to any change in awards at, below, or slightly above the median. See id. at 26 table 9 .

${ }^{78}$ See Sentencing Reform Act of 1984 , Pub. L. No. $98-473,98$ Stat. 1987 (codified at 18 U.S.C. \$\$ 3551-99 (1982 \& Supp. IV 1984)); Tonry, Real Offense Sentencing: The Model Sentencing and Corrections Act, 72 J. CRIM. L. \& CRImINolOGY I550, 155I \& n.5 (I98I).

79 In Anglo-Saxon England, a system of "bots" specified the compensation owed for various injuries, see H. Adams, H. Lodge, E. Young \& J. LaUghlin, Essays in ANglo-Saxon Law $27 \mathrm{I}-73,278-79(\mathrm{I} 878)$, and workmen's compensation schemes provide schedules for financial awards today, see 2 A. LARSON, THE LAW OF WORKMEN'S COMPENSATION $\$ \$$ 57.I4, 58.II, 58.23 (1983). Damages guidelines might be administered in a more flexible manner than these precursors; jurors could be instructed to depart from the guidelines if the guidelines did not seem to fit the circumstances of specific cases. 
tasks, and to enagage in professional study of how best to perform their duties. 80

The dangers of excessive discretion include not simply capriciousness but also discrimination. After controlling for such variables as the type of injury, the amount of lost income, the age and occupation of the plaintiff, the type of lawsuit and the type of defendant, a recent study of damage awards in Cook County reported that black plaintiffs recovered significantly lower amounts than similarly situated white plaintiffs. ${ }^{81}$ The same study indicated that the perceived depth of a defendant's pockets had an enormous impact on the jury's determination of damages. For example, after establishing a defendant's negligent maintenance of a building or other property, a seriously injured plaintiff would be likely to recover $\$ 37,000$ from an individual, $\$ 98,000$ from a governmental agency, and $\$ 16 \mathrm{I}, 000$ from a corporation. 82

Not only could "damage commissions" begin to remedy these inequalities; they could also focus in a far more systematic fashion than individual juries on the long-range effects of damage awards. They could decide, for example, whether fair compensation requires the sort of awards that have led doctors to abandon the specialties for which they were trained, drug manufacturers to cease their production of vaccines, and guest ranches to forbid their patrons from riding unescorted or at gaits faster than a walk. ${ }^{83}$

80 At the same time, because groups tend to "regress toward the mean," greater uniformity might be expected in decisions by twelve-person groups than in decisions by single individuals.

In England, where the civil jury has virtually disappeared, the judiciary has developed reasonably precise standards for damage awards. See, e.g., Wright v. British Rys. Bd., [1983] 2 All E.R. 698 (H.L.); Gardner v. Gardner (C.A. Oct. 22, 1985) (available on LEXIS, Enggen Library, Cases file); Sims v. William Howard \& Son Ltd., [1964] 2 W.L.R. 794 (C.A.), noted in 78 HARV. L. REV. 676 (1965).

81 For example, a case that led to a damage award of $\$ 34,500$ for a black plainitiff would be likely to yield an award of $\$ 46,600$ for a white plaintiff. See A. Chin \& M. Peterson, DeEp Pockets, EMrty Pockets: Who Wins in Cook County Jury Trlals viii-ix, 37-4I (Rand Inst. for Civil Justice 1985 ). The study includes in its analysis some cases in which information concerning the amount of lost income was unavailable. Its authors recognize that this omitted information might have explained part of the apparent racial disparity. See id. at 39 .

82 See id. at 43 table 4.5 . On hearing these figures, my colleague Richard Epstein commented, "So much for the Hand formula!"

83 See M. Block, Professional Liability Insurance and Obstetrical Practice 5-7 (1985) (one fourth of surveyed members of the Michigan Section of the American College of Obstetrics and Gynecology reported that the cost of liability insurance had led them to stop delivering babies altogether); Institute of Medicine, Division of HEalth Promotion and Disease Prevention, Vaccine Supply and Innovation i 8 (I985) (pharmaceutical companies have withdrawn from vaccine manufacturing and increasingly have cited litigation costs and the difficulty of obtaining insurance as major factors in their decisions - their withdrawals have "threaten[ed] the nation's supply of vaccine"); Middleton, The Medical Malpractice Wars, Nat'l L.J., Aug. 27, I984, at I (cost of unnecessary tests and other "defensive medicine" estimated at $\$ 5$. I billion by American Medical Association study). 
As this Article will explain in greater detail, ${ }^{84}$ effective damages guidelines, when coupled with other reforms, might make plaintiffs and their attorneys less insistent on jury trials and more willing to substitute other, less expensive forms of adjudication. Guidelines also might facilitate appropriate private settlement. Today's uncertainty in damage awards motivates risk-averse litigants to settle out of fear that they may become the victims of caprice and unequal treatment at trial. Certainty, however, could motivate settlement for a better reason. Litigants who knew reasonably well how a trial would end would have little reason to do battle. ${ }^{85}$

\section{Cajolery Conferences}

Despite the roulette-wheel qualities of our damage awards, the extraordinarily burdensome nature of our procedures, and the lengthy wait necessary to secure a trial, some litigants persist in demanding adjudication. When a litigant comes close to the end of the queue, he is likely to encounter a vivid manifestation of our society's reluctance to provide adjudicative services. His case typically is scheduled for something that procedural rules euphemistically call a pretrial conference - commonly an off-the-record, in-chambers proceeding that might better be characterized as an antitrial conference. Professor Galanter has described how views of this conference have changed since its introduction in the federal courts in I938, documenting a gradual glorification of the judge's role in inducing the parties to

84 See infra pp. 1853-54.

85 The assertion that both certainty and uncertainty can promote settlement may seem contradictory, but it is not. Some settlements occur because people can predict trial outcomes and see little reason to litigate. Others occur because people cannot predict trial outcomes and seek to minimize the risks of defeat and of unfavorable damage awards.

This Article offers no assessment of the net quantitative effects of these differing motivations. Anecdotal evidence suggests that when a new source of uncertainty appears in an adjudicative system (when, for example, a visiting judge not known to the local bar is assigned to a local court), the number of settlements is likely to increase. At the same time, a usual condition of litigation is disagreement about the probable outcome of a lawsuit. Greater certainty tends to reduce the likelihood of this disagreement.

Uncertainty can in fact be regarded as having two countervailing effects. When people are risk averse, it provides a motive for settlement in itself. At the same time, it increases the likelihood of disagreement concerning probable outcomes. This disagreement increases the likelihood of litigation. (When uncertainty does not lead to divergent estimates of probable outcomes - that is, when both parties assess the uncertainty in the same way - its principal effect is less ambiguous; it encourages risk-averse litigants to settle.) Which of the countervailing effects predominates (or whether the relationship is curvilinear with mid-level uncertainty leading to the most litigation) is a matter of speculation. The argument in the text is simply that settlements motivated by knowledge of the likely outcome are qualitatively different from those motivated by the opposite phenomenon. 
settle. ${ }^{86}$ Indeed, the Federal Rules now list "facilitating the settlement of the case" as an explicit objective of the conference. ${ }^{87}$

A national survey reports that only about one-fifth of America's trial judges describe their typical posture as one of nonintervention in settlement discussions. Most describe their role as to "intervene subtly - through the use of cues/suggestions." One-tenth describe their typical practice as to "intervene aggressively - through the use of direct pressure." 88

Professor Galanter quotes remarks made by Judge Frederick Lacy to newly appointed federal judges - remarks that have been widely distributed by the Federal Judicial Center:

[T] he judge should actively and firmly (but not coercively) seek to settle every case on his docket. . . . I suggest that no more than five per cent of each year's civil terminations should result from fully tried cases. The other ninety-five percent, if not settled by counsel themselves, should be settled with the judge's active intervention. ${ }^{89}$

The federal courts achieved Judge Lacy's statistical goal in I984; the percentage of cases terminated during or after trial fell to five percent. 90 Moreover, the "active intervention" endorsed by Judge Lacy is not confined to federal courts. In California, state courts declare "trial holidays" during which judges devote their energies entirely to the promotion of settlements. These "holidays" sometimes last for weeks. ${ }^{91}$ In Cook County, Illinois, every case in which a plaintiff seeks $\$ 15,000$ or more in damages is routed through the Mediation Division of the Circuit Court. The seven judges of this division conduct their business in "offices," not chambers. The walls

${ }^{86}$ Galanter, “. . . A Settlement Judge, Not a Trial Judge”: Judicial Mediation in the United States, I2 J.L. \& Soc'y I (1985); see M. Galanter, ThE EMERgence of THE Judge as a Mediator in Crvil Cases (Working Paper 1984-5, Disputes Processing Research Program, University of Wisconsin-Madison Law School, I984); Oesterle, Trial Judges in Settlement Discussions: Mediators or Hagglers?, CORNELL L.F., June 1982, at 7.

87 Fed. R. Civ. P. I6(a)(5); see Manual for Complex Litigation Second \$ 23. I 1 (1985) ("As the case progresses and both the judge and counsel learn more about it, the court should urge the parties to consider - and reconsider - the possibility of settlement in the light of what has occurred and, perhaps more important, what may be ahead if litigation is pursued."). The authors of the original federal rules maintained that settlement discussions were not an appropriate part of pretrial conferences. See Clark, Objectives of Pre-Trial Procedure, 17 OHо ST. L.J. I63, I67 (1956).

88 J. Ryan, A. Ashman, B. Sales \& S. Shane-Dubow, American Trial Judges: Their WORK STYLES AND PERformances I77 (1980). In a separate poll, $75 \%$ of the federal court judges surveyed and $56 \%$ of the state court judges reported that they initiated settlement discussions in jury cases. Yankelovich, Skelly \& White, Study of the Role of CoURTS 83 (U.S. Dep't of Justice, Office for Improvements in the Adm'n of Justice 1980).

89 Galanter, supra note 86 , at 4 (footnote omitted).

90 ADMIN. OFFICE of THE U.S. CouRTs, supra note $6 \mathrm{r}$, at 280 table $\mathrm{C}_{4}$.

${ }^{91}$ See Menkel-Meadow, Judges and Settlement: What Part Should Judges Play?, Trial, Oct. 1985 , at 24,28 . 
are painted in pastel colors, and classical music plays in the background. The judges have had psychological training in mediation. ${ }^{92}$ Whether the message is overt, veiled, or denied, uninvited judicial participation in settlement discussions inevitably suggests that our society affords adjudicative services only grudgingly. ${ }^{93}$

\section{$E$. The Strategic Infliction of Waste}

A final source of unfairness in civil settlement is the power that American procedure gives each party to drive up the other's unrecoverable costs. With sporadic exceptions, the extent to which, and the ways in which, lawyers and litigants use their power to force expenditures by their opponents has not been the subject of systematic empirical study. ${ }^{94}$ Nevertheless, American procedure plainly invites abuse; and the existence of an essentially unchecked power to abuse is objectionable in principle however infrequently lawyers and litigants take advantage of it.

An extreme example of unfair cost-infliction in settlement negotiations is the "strike suit" - the meritless lawsuit that gains settlement value only because the defendant must expend resources to demonstrate its lack of merit.95 Another example is the extensive invocation of discovery procedures by a party who hopes that his opponent will balk at the expense and settle on favorable terms. ${ }^{96}$ Other examples

92 Remarks of James J. Alfini, American Bar Foundation Conference on the Judicial Role in Settlement Activity, in Chicago (Nov. 7, 1985).

${ }^{93}$ In effect, when an American litigant seeks a principled resolution of his dispute, he often is told what Bernhard Goetz was told: "Please, friend, let's be reasonable. Wouldn't you really rather mediate?" Indeed, when the victim of an assault seeks damages from a mugger, a judge in Chicago may invite the parties to negotiate to the strains of Debussy.

94 So far as I am aware, the exceptions - important ones - are all studies of discovery abuse. See, e.g., Brazil, Civil Discovery: Lawyers' Views of Its Effectiveness, Its Principal Problems and Abuses, I980 AM. B. Found. RESEARCH J. 787 [hereinafter cited as Civil Discovery: Lawyers' Views]; Brazil, Views from the Front Lines: Observations by Chicago Lawyers About the System of Civil Discovery, I980 AM. B. Found. RESEARCH J. 217; C. Ellington, A Study of Sanctions for Discovery Abuse (U.S. Dep't of Justice, Fed. Justice Research Program 1979).

95 Richard Posner has argued that strike suits ought to be rare: "In the case of the truly groundless claim the defendant knows that if he calls the plaintiff's bluff the plaintiff will not throw away good money litigating the case, and the plaintiff should know that the defendant knows this." Posner, supra note 7 , at 433 . This argument appears to assume substantial symmetry in the ability to inflict litigation costs (including pretrial litigation costs), a condition that is unlikely to exist in a large number of situations. Posner's argument also appears to assume an equal ability to bear costs, a condition that may not exist in cases of wealth disparity. See Rosenberg \& Shavell, A Model in Which Suits Are Brought for Their Nuisance Value, 5 INT'L REv. L. \& ECON. 3 (I985).

${ }^{96}$ Between $80 \%$ and $92 \%$ of a sample of attorneys in large-stakes cases answered affirmatively when asked if "the purpose of imposing work burdens or economic pressure on another party or attorney ever had been a factor in affecting their use of discovery tools." Civil Discovery: Lawyer's Views, supra note 94 , at 857 (the overall percentage of affirmative responses 
include the filing of burdensome pretrial motions partly because "[i]t takes time to refute even a bad contention"97 and the selection of a forum for litigation that an opponent will find costly and inconvenient. ${ }^{98}$ Adopting the British and Continental rule that a losing litigant must pay the winner's litigation expenses, including attorney's fees, would provide a substantial deterrent to the deliberate infliction of costs as a negotiating strategy. Litigants would be less likely to drive up their opponents' costs if they ran a significant risk of bearing these costs themselves. ${ }^{99}$ Whether our failure to adopt a cost-shifting rule encourages or discourages litigation is problematic; ${ }^{100}$ but regardless of how this empirical issue is resolved, a procedure that makes it tactically advantageous to increase the costs that one's opponent must incur in the effort to obtain justice seems unsound. ${ }^{101}$

was not reported, but in every subgroup of the sample affirmative responses were between $80 \%$ and ${ }_{92} \%$ ). Antitrust lawyers admitted using this cost-infliction strategy in about one-third of their cases over a five-year period. See id. at 857-58.

97 See Alschuler, The Prosecutor's Role in Plea Bargaining, 36 U. CHI. L. REv. 50, 56 (Ig68).

${ }^{98}$ Cf. Civil Discovery: Lawyers' Views, supra note 94 , at 856 (describing the practice of "noticing depositions for . . . expensive to reach . . . places").

99 The academic literature has paid inadequate attention to this reason for cost shifting. Indeed, some scholars have argued that cost shifting might increase litigation expenditures. See, e.g., Goodhart, Current Judicial Reform in England, 27 N.Y.U. L. REV. 395, 405-06 (1952); Mause, Winner Takes All: A Re-Examination of the Indemnity System, 55 Iowa L. REv. 26, 36 (1969). The primary concern of these commentators has been that litigants might fail to hold their own expenses down when they knew that these expenses might be borne by their opponents. So long as litigants recognized a significant risk that they would bear litigation costs themselves, however, the incentive to refrain from wasteful spending would remain strong. Indeed, utterly wasteful spending would be unlikely even on the part of a litigant who was confident of victory at trial. Not only would this wasteful spending fail to benefit the litigant, but it also would not be compensable under any conceivable cost-shifting rule. The current American rule, by contrast, encourages litigants to inflict costs on their opponents when these costs yield no economic return but merely provide settlement leverage.

100 See Shavell, supra note 23 , at 58-69.

101 A patent lawyer in Chicago, most of whose clients are substantial business entities, told me, "In many cases, settlement figures are determined by which side runs out of money first." Interview with Ronald E. Larson, in Chicago (Aug. 28, 1985). Arthur R. Miller has observed, "In many ways, contemporary federal litigation is analogous to the dance marathon contests of yesteryear. The object ... is to . . . drift . . . to the litigation music for as long as possible, hoping that everyone else will collapse from exhaustion." Miller, supra note 39 , at 9 .

The subject of cost shifting has generated an enormous amount of writing. This article does not review the many arguments advanced on both sides of the issue. For a useful summary and analysis, see Rowe, The Legal Theory of Attorney Fee Shifting: A Critical Overview, I 982 DUke L.J. 651 .

The cost-shifting issue may be simpler, however, than a river of consequentialist analysis has made it seem. The same comparative judgment that requires a losing litigant to bear the medical or other expenses at issue in a lawsuit also supports requiring this litigant to bear the costs of legal proceedings. Although scholars have advanced strained distinctions between an injured party's legal expenses and his medical expenses, no one has advanced a plausible basis for judging a successful litigant a more appropriate source of litigation financing (in whole or 


\section{The Perils and Promises of Judicial Case Management}

The proposal for a revised system of civil procedure that this Article will advance is designed not only to make adjudicative services more available but also to satisfy two other requisites of American civil procedure. One is the need to promote more effective "case management" during the pretrial period (controlling discovery abuse, discouraging procrastination by lawyers, and the like). The other is the need to ensure judicial impartiality, a task made more difficult by "case management."

"Managerial judging" has emerged in recent years as an ad hoc response to some of the defects of American procedure noted in this Article. To limit the strategic infliction of waste, to promote a more rapid disposition of cases, and to reduce the high costs of justice, American judges now supervise pretrial activities much more actively than had been thought appropriate or necessary in earlier decades. Opponents of this development have claimed that the virtues of pretrial case management remain to be proven ${ }^{102}$ while proponents have discounted the threat to judicial disengagement and dispassion posed by this activity. ${ }^{103}$ In dismissing each other's contentions, both sides have been wrong.

Defenders of "managerial judging" commonly assert that it makes courts more productive. With respect to one managerial activity, however - judicial participation in settlement discussions - this

in part) than his opponent. The balance of equities seems to favor cost-shifting even in close cases, and the current American non-cost-shifting rule extends beyond these cases to others in which the losing litigant's position has been far less strong than his opponent's.

Similarly, the fear that risk-averse disputants might be "too reluctant" to litigate in a costshifting system does not offer a principled justification for the current American rule. The argument's "missing link" is a demonstration that the desirable airing of plausible but losing contentions should be subsidized, not by the public or some other asserted beneficiary of this activity, but by a group of people who already bear the activity's nonfinancial burdens, who do not benefit from it, and who have been found to have done nothing wrong. When the perverse economic incentives provided by our current rule are added to the equitable reasons for cost shifting, the case for a general cost-shifting rule like those employed in every advanced legal system except our own and Japan's seems compelling.

Perhaps it bears reiteration that cost-shifting is desirable only for those litigation expenses that are appropriately borne by private litigants. For reasons that this Article has explained, substantial governmental subsidization of private litigation is appropriate. See supra pp. I8I I17.

It also merits mention that the baseline from which to measure "loss" for the purposes of applying a "loser pays" rule need not be a litigant's position prior to the fling of a lawsuit. Whether the litigant has improved his position by litigating rather than accepting his opponent's most recent settlement offer is probably the appropriate inquiry. See infra p. 1852 \& note I8o.

102 See Resnik, supra note 6, at 414-24.

103 See Flanders, Blind Umpires - A Response to Professor Resnik, 35 Hastings L.J. 505 (1984); Peckham, A Judicial Response to the Cost of Litigation: Case Management, Two-Stage Discovery Planning and Alternative Dispute Resolution, 37 RuTGERS L. REv. 253, 260-67 (I985). 
claim may be unfounded. Most empirical studies have concluded that judicial intervention neither increases the aggregate number of settlements nor reduces case processing time. ${ }^{104}$ Nevertheless, judicial monitoring of case preparation by lawyers - for example, the establishment and enforcement of discovery schedules - appears to speed the disposition of cases substantially. ${ }^{105}$

Even apart from its virtues in enhancing "productivity," judicial supervision of evidence-gathering and other pretrial activities seems

104 See T. Church, A. Carlson, J. Lee \& T. Tan, Justice Delayed: The Pace of Litigation in Urban Trial Courts 33 (1978); S. Fianders, Case MaNagement and Court Management in United States District Courts 37-39 (Federal Judicial Center, District Court Study Series 1977); R. Gillespie, Judicial Productivity and Court Delay: AN Exploratory ANalysis of the Federal District Courts at xix, 46, 49 (I977); M. Rosenberg, The Pretrial Conference and Effective Justice 28-29 (I964); H. Zeisel, H. Kalven \& B. Buckhol2, Delay IN The CourT I4I-54 (2d ed. 1978); Wall \& Schiller, Judicial Involvement in Pretrial Settlement: A Judge is Not a Bump on a Log, AM. J. Trial Advoc., Summer 1982 , at 27,37 .

Unlike the works cited above, an unpublished study of pretrial conferences in Ontario, Canada, reported a positive correlation between judicial settlement activity and the frequency of settlement. See G. Watson, Judicial Mediation: The Results of a Controlled Experiment in the Use of Settlement-Oriented Pretrial Conferences (I984) (unpublished manuscript) (describing research conducted by M. Stevenson, G. Watson, and E. Weissman). The methodology of this study was superior to those employed in earlier works, for only the Ontario study reported the results of a fully controlled experiment. The study focused, however, on settlement conferences in cases scheduled for trial before judges rather than juries. Although these cases would not have been tried by the judges who conducted the settlement conferences, the ability of one judge to predict the decisions of a second judge may be superior to a judge's ability to predict the decisions of a jury. In addition, the positive correlation that the study reported was attributable to the success of only a minority of the judges who conducted settlement conferences. The ability of some judges in a nonjury system to induce settlements does not demonstrate that judges in a jury system could be similarly successful.

The reported failure of judicial intervention to increase settlement rates in the United States appears somewhat counterintuitive and is at odds with the impressions of most practicing lawyers. A survey of 1900 attorneys who had recently litigated cases in United States district courts reported, "A staggering 85 percent ... agree that involvement by federal judges in settlement discussions [is] likely to improve significantly the prospects for achieving settlement." W. Brazil, Settling Civil Suits I (American Bar Ass'n Judicial Adm. Div. 1985); accord Kritzer, The Judge's Role in Pretrial Case Processing: Assessing the Need for Change, 66 JUDICATURE 28, 36 (I982).

Marc Galanter has noted that today's American trial judges are less likely to have had long careers as trial lawyers than their predecessors; they often may have had less experience in assessing the "worth" of untried cases than the lawyers who appear before them. Remarks of Marc Galanter, American Bar Foundation Conference on the Judicial Role in Settlement Activity, in Chicago (Nov. 7, 1985). At the same time, the assessment of a case by an objective third party might be expected to have some effect in promoting settlement even when this third party lacks extraordinary expertise. The danger that a refusal to settle might color a judge's later rulings also might encourage settlement.

105 See, e.g., S. Flanders, supra note 104, at 130 table 59; D. Neubauder, M. Lifetz, M. Luskin \& J. Ryan, Managing the Pace of Justice: An Evaluation of LEAA's Court Delay Reduction Programs (Nat'l Inst. of Justice 198I); Church, The "Old and the New" Conventional Wisdom of Court Delay, 7 Just. Sys. J. 395, 405 (1982). 
desirable. A judge cannot know whether a discovery request or a request for a postponement is abusive or appropriate unless he is familiar with the issues in the case and knows what evidence has been gathered. If only because of its enhancement of the quality of pretrial rulings, "managerial judging" seems likely to remain a longterm feature of the American legal system. 106

As originally enacted, the Federal Rules of Civil Procedure envisioned a lawyer-controlled pretrial process that would operate effectively with only occasional judicial oversight. As Arthur R. Miller has commented, however, the rules' premises now appear naive: "The vision that adversarial tigers would behave like accommodating pussycats ... has not materialized. ... The truth is that we have a pretrial system characterized by over-litigiousness, hyperactivity, and marginal behavior by attorneys, producing excessive cost and delay."107

Judges and rulemakers continue their efforts to tame the tigers and recently have developed more sophisticated sanctions for lawyers who have crossed an ill-defined line of abuse. ${ }^{108}$ Although the returns are not in, and although the innovations are likely to prove beneficial in many situations, the principal effect of these changes may be to generate more frequent satellite hearings and an ever more complex pretrial process.

In the end, short of resurrecting a regime in which each litigant must produce his own evidence without significant help from his opponent or the court, there may be no realistic alternative to a more direct judicial involvement in evidence-gathering. A prominent recent effort illustrates the hopelessness of mechanisms for limiting pretrial abuse without this involvement. Some jurisdictions have adopted local rules of court that, without regard to the nature of the case, fix the number of interrogatories that litigants may submit to their opponents. ${ }^{109}$ These rules invite frequent requests for dispensation, are likely to operate unfairly when judges hesitate to grant these requests, encourage artful draftsmanship by lawyers who strive to compress many queries into one, and generate linguistic disputation as opposing

${ }^{106}$ Indeed, a return to the premanagerial era seems nearly inconceivable, especially in complex cases. Cf. Manual fOR Complex Litigation SECond \$ 20. I (1985) ("Lawyers and judges are virtually unanimous ... on the critical need for early active involvement by the judiciary in managing complex litigation.").

${ }^{107}$ Miller, supra note 39 , at 15 (footnotes omitted).

${ }_{108}$ See, e.g., FED. R. CIV. P. II, 26(g), I6(f) (1983 amendments); Miller, supra note 39, at 24-29 (commenting favorably on this development).

${ }^{109}$ See, e.g., D. Alaska R. 8(C); C.D. Cal. R. 8.2.I; D. NEB. R. $9(\mathrm{C})$; W.D. OKLA. R. io(A); see also A.B.A. Section of Litigation, Report of THE SPECial CoMmittee for the Study of Discovery Abuse i8, 20 (1977); Judicial Conf. of the United States, Comm. on Rules of Prac. \& Proc., Preliminary Draft of Proposed Amendment to the Federal Rules of Civil Procedure, 77 F.R.D. 613, 645-49 (1978). 
lawyers protest this stratagem. Rather than prod advocates to do justice, perhaps courts ought to do justice themselves. ${ }^{110}$ Greater judicial involvement in evidence-gathering would obviate the need for artificial rules and satellite hearings. When judged by the norms of other complex activities, litigation in America appears undermanaged rather than overmanaged. Our system of justice could profit from more "managerial judging" rather than less.

As a path-breaking study by Judith Resnik has contended, ${ }^{111}$ however, active pretrial case management involves a significant departure from traditional concepts of the appropriate judicial role and may threaten judicial impartiality. The danger is not simply that managerial judges may develop what Professor Miller has called "a mystique of disposition uber alles"112 (although an emphasis on disposition for its own sake has become a striking and distressing characteristic of the American judiciary). ${ }^{113}$ More fundamentally, a judge who has gained familiarity with the facts of a case during his pretrial activities is unlikely to relish the prospect of hearing the evidence again at trial. This judge may regard an elaborate adversarial proceeding as unnecessary (as indeed it often is) and may attempt to "cut through the foliage" in order to save the taxpayers, the litigants and - of course - himself the bother of a costly and largely duplicative proceeding. The emergence of a far more aggressive judicial participation in settlement discussions at the same time that other forms of case management have exposed judges to piecemeal previews of possible trials is probably no coincidence. ${ }^{114}$

Without affording the parties a full opportunity to be heard, a "managerial" judge may, in effect, decide a case and encourage settlement on terms that correspond to his barely provisional views. When the "pretrial" judge is also the judge who will conduct a trial if settlement is declined, his "advice" may carry more weight than friendly advice should. Whether or not the judge intends to convey this message, his prodding may suggest that he much prefers the role of a "settlement judge" to that of a "trial judge"; 115 it also raises the

${ }^{110} \mathrm{Cf}$. Alschuler, The Preservation of a Client's Confidences: One Value Among Many or a Categorical Imperative?, 52 U. CoLo. L. REv. 349, 354 (I98I) ("Lawyers simply are not appropriate figures to correct the defects of our adversary system. Their hearts will never be in it, and ... it is unfair to both their clients and themselves to require them to serve two masters.").

111 See Resnik, supra note 6.

112 Miller, supra note 39 , at 35 .

113 See, e.g., Alschuler, The Trial Judge's Role in Plea Bargaining (Part I), 76 CoLum. L. REv. 1059, I099-1 102 (1976) (describing the courthouse game of "disposition rate rivalry" and the penalties that losing judges may incur).

${ }^{114}$ In its indignant insistence that pretrial case management is unrelated to judicial intervention in settlement discussions, Steven Flanders' critique of Resnik's article apparently misses the article's central point. See generally Flanders, suprd note to3.

115 See Galanter, supra note 86 , at $\mathbf{I}$. 
possibility that an "unreasonable" refusal to settle may color his rulings at trial. To be sure, disputants often may value mediation by an impartial third party. This mediation may facilitate settlement in ways that both of them desire and may improve the quality of any agreement that they reach. The dangers of hasty judgment, of failure to afford an adequate opportunity to be heard, of partiality at trial, and of undue pressure to settle do not always accompany managerial judging. Nevertheless, these dangers require much more effective correctives than our legal system currently provides.

\section{TOWARD a Solution}

This Article has noted a number of reforms that would promote greater fairness in the settlement of civil lawsuits - adopting a costshifting, "loser pays" rule that would limit the ability of litigants to encourage settlement by driving up their opponents' expenses, ${ }^{116}$ awarding prejudgment interest on nonliquidated damages and thereby limiting the extent to which delay serves as a one-sided lever benefiting defendants, ${ }^{117}$ and developing "damages guidelines" that would reduce the fear of jury capriciousness, a fear that currently encourages all but the boldest of litigants to settle. ${ }^{118}$

Although each of these reforms would contribute to the quality of negotiated settlements, none would address directly the principal source of unfairness in civil settlement, the shortage of adjudicative services. Certainly the most effective way to remedy this shortage would not be to pour additional resources into our existing adjudicative machinery - something that Americans have done in recent years without much effect. ${ }^{119}$ In discussing the shortage of adjudicative services in criminal cases, I wrote, "The key to eliminating America's widespread subversion of the right to trial may lie in making trial a more workable, more affordable procedure." 120 This objective could be accomplished more easily in civil than in criminal cases. ${ }^{121}$

116 See supra pp. 1830-3r \& note Iоr.

117 See supra p. 1823.

118 See supra pp. 1825-28.

${ }^{119}$ See R. POSNER, supra note Io, at 27 table 2.I; BuREaU of JUSTICE STATISTICS, U.S. DEP'T OF Justice, supra note 69 , at 20 table 1.4 .

${ }^{120}$ Alschuler, supra note 5 , at 970.

121 The federal Constitution, as interpreted since the due process revolution, mandates much of the current complexity of American criminal procedure, and the public objectives of criminal proceedings (as well as the indigency of most defendants) make any significant financing of criminal trials through user fees inappropriate. Accordingly, the most promising path toward reform of our nonadjudicative criminal process probably lies in substituting a less restrictive form of bargaining for plea bargaining - bargaining for waiver of the right to jury trial but not for waiver of the right to trial before a court. In Philadelphia, America's fifth largest city, nonjury trials have in fact become the most common method of resolving criminal cases; the 
More detailed development of this proposal must await a description of some worthwhile institutions in America, England, and Continental Europe that mark an appropriate path toward reform. In essence, however, the proposal calls for a more active judicial participation in what now are regarded as pretrial activities - the disclosure of each party's evidence to the other and the gathering of evidence from third parties. This judicial participation, coupled with other innovations, would permit the conversion of these "pretrial" activities into something more - an impartial adjudication that the parties often might regard as sufficient to resolve their dispute. Once all the evidence had been gathered, the judge who had supervised its gathering could resolve each case on its merits. Either party would be free to treat this resolution as advisory and to seek a formal, adversarial trial before a different judge or a jury. Nevertheless, a litigant would be required to bear the costs of this second proceeding including both the full costs of the proceeding to the government and the litigation expenses reasonably incurred by his opponent - if the outcome of the proceeding proved no more favorable to him than the outcome of the initial procedure.

\section{A. Promising Progenitors of Reform}

This Article has suggested that our system of civil procedure requires three relatively far-reaching reforms: first and foremost, the provision of a simplified form of adjudication that would make justice more accessible; second, a closer judicial control of evidence-gathering; and third, an effective remedy for the loss of impartiality that sometimes accompanies "managerial judging." A number of institutions and practices - both in our own legal system and in others - point the way toward the realization of these objectives.

I. The Pretrial Duties of American Magistrates and English Masters. - One relevant practice is the use of magistrates in United States district courts to supervise discovery and to conduct pretrial

principal reason has been that convictions at these trials do not ordinarily lead to more severe sentences than would have followed bargained pleas of guilty. See id. at 1024-43; Schulhofer, Is Plea Bargaining Inevitable?, 97 HARV. L. REv. 1037, 1057-62 (1984).

Although Philadelphia affords criminal defendants an unfettered right to adjudication and thereby avoids many of the defects of plea bargaining, that city's "waiver bargaining" appears virtuous only in comparison to practices elsewhere. Philadelphia, like most other American jurisdictions, discourages jury trials through the threat of more severe sentences than would follow convictions at nonjury trials. It thereby penalizes the exercise of a constitutional right and bases criminal punishment partly on defendants' strategies rather than on their crimes. In civil cases, by contrast, America can escape adjudicative procedures that promise too much and deliver too little without dealing in the currency of human liberty. It can provide a substantially simplified form of adjudication to all litigants and can, at the same time, retain more elaborate procedures for litigants willing to run the risk of paying the economic cost of these procedures if they lose. 
conferences - a practice that is frequent but unregularized, varying from judge to judge and from court to court. ${ }^{122}$ Another is the use of masters in England to conduct all pretrial proceedings, a practice that ensures a much more systematic separation of pretrial and trial functions than do American practices. English masters supervise pleading, discovery, issue identification, and scheduling and also make some case-dispositive rulings (for example, dismissing cases in which plaintiffs have failed to state valid claims). ${ }^{123}$ Although the masters' rulings are subject to interlocutory and ordinarily de novo review, appeals are infrequent, largely because reversal rates are low and because courts impose costs, including attorneys' fees, on parties who lose on appeal. ${ }^{124}$ Linda J. Silberman, the author of a careful and detailed study of English masters, has noted that the English system requires the final resolution of all procedural issues prior to the commencement of trial. ${ }^{125}$ Seven years before Resnik focused attention on the problems of managerial judging, Silberman commented:

The English .... see an advantage in insulating their judges from the parties' contests over interlocutory or other collateral matters: keeping pretrial proceedings away from the presiding trial judge prevents matters arising at a preliminary stage from influencing or prejudicing the judge when he presides in the context of a full trial. 126

An English-style separation of the trial and pretrial functions could facilitate closer judicial supervision of pretrial activities and, at the same time, provide a more effective corrective for the partiality that may arise from this supervision. Rather than seek an accomodation of conflicting values, our legal system could pursue both values more effectively. A clearer division of labor would also eliminate the danger that a "pretrial" judge might deliberately or inadvertently coerce settlement through an explicit, implicit, or even misperceived threat of

122 See C. Seron, The Roles of Magistrates in Federal District Courts 44 table 9 (1983); Silberman, Masters and Magistrates Part II: The American Analogue, 50 N.Y.U. L. REV. I297, I300-04, I338-4I (1975). In noting some virtues of the use of magistrates to supervise pretrial proceedings, I refer only to the benefits of assigning special pretrial responsibilities to a distinct set of judicial officers. I do not consider whether this use of magistrates delegates excessive authority to people who lack the guarantees of impartiality that article III mandates for federal judges. See Geras v. Lafayette Display Fixtures, 742 F.2d 1037, 1045 (7th Cir. 1984) (Posner, J., dissenting). See generally Resnik, The Mythic Meaning of Article III Courts, 56 U. CoLo. L. REv. 58I (1985) (exploring the labyrinth of the Supreme Court's article III decisions).

${ }^{123}$ See Silberman, Masters and Magistrates Part I: The English Model, 50 N.Y.U. L. REv. I070, I079-I105 (1975).

124 See id. at 1086.

125 See id. at III6-17.

126 Id. at I Io6-o7 (footnote omitted). 
retaliation at trial. ${ }^{127}$ Nevertheless, this separation of functions would not make adjudicative services more available.

2. "Court-Annexed Arbitration." - The "court-annexed arbitration" programs of a number of American jurisdictions do make adjudication more accessible. ${ }^{128}$ To date, these programs have been limited to cases in which the stakes are relatively small. ${ }^{129}$ Their common attribute is simply the referral of eligible cases to mandatory pretrial arbitration. The arbitration, typically conducted by a practicing lawyer, a retired judge, or a panel of three lawyers, consists of a quasi-judicial hearing and a resolution of the dispute. Either party may reject the arbitrator's decision and insist on a trial before a judge or a jury.

In some programs, rejection of the arbitrator's award risks no sanction; in others, a party who fails to improve his position at trial (that is, a plaintiff who recovers less than the arbitrator has awarded or a defendant who is required to pay more) is ordered to pay arbitration costs or court costs (and, in a very few programs, attorneys' fees that the opposing party has incurred). ${ }^{130}$ To some extent, courtannexed arbitration resembles the older and better established practice of trying small-stakes cases initially in courts not of record and then permitting trials de novo in courts of general jurisdiction. ${ }^{131}$ It also resembles the practice of requiring litigants in medical malpractice

127 English masters do not appear to participate in settlement discussions. See id. at IIII \& n.270.

128 As of January 1985, I 6 states and II federal district courts had authorized court-annexed arbitration programs. See P. Ebener \& D. Betancourt, Court-AnNEXed Arbitration: The National Picture 2 (Rand Inst. for Civil Justice 1985). See generally D. Hensler, Court-ANNEXEd ARBitration in the STATE TRIAL Court System i2 (1984); E. Lind \& J. Shapard, Evaluation of Court-Annexed Arbitration in Three Federal District CouRTs (1983); Levin, Court-Annexed Arbitration, I6 U. Mich. J.L. REF. 537 (I983); Nejelski \& Zeldin, Court-Annexed Arbitration in the Federal Courts: The Philadelphia Story, $42 \mathrm{MD}$. L. Rev. 787 (1983); Court-Ordered Arbitration: A Report on the First National Conference on Court-Ordered Arbitration, Dispute RESOLUTION FoRuM, Aug. I985, at I [hereinafter cited as National Conference Report]; Note, Compulsory Judicial Arbitration in California: Reducing the Delay and Expense of Resolving Uncomplicated Civil Disputes, 29 Hastings L.J. 475 (1978).

One reason that "court-annexed arbitration" has not attracted the attention it deserves may be that someone gave the practice a foolish name (how does one annex a court to an arbitration?) and then slipped the name amidst a long list of appalling, nonadjudicative "alternative dispute resolution" techniques. One typically hears about court-annexed arbitration just after a judge has given an enthusiastic description of his court's "Getting-to-Yes-With-Your-Mugger Program."

129 The maximum amount at issue is as high as $\$ 150,000$ in some federal programs but is typically $\$ 50,000, \$ 25,000, \$ 15,000, \$ 10,000$ or even less in state programs. See P. EBENER \& D. BEtanCouRT, supra note I28, at 9-Io table 3; see also E. LiND \& J. Shapard, supra note 128, at 3-4; CaL. Crv. Proc. Code \$ I I41.12 (West r982). Even in California (where the maximum amount at issue is $\$ 15,000$ in most counties and $\$ 25,000$ in others) and in Pittsburgh (where the maximum amount at issue is $\$ 20,000$ ), about $60 \%$ of all civil damage actions are referred to arbitration. See D. HENSLER, supra note 128, at 7 , I2.

${ }^{130}$ See P. EbEner \& D. Betancourt, supra note 128 , at 9-10 table 3.

131 See, e.g., VA. CODE \& I6-IO6 (I982). 
disputes to submit their evidence initially to a panel of arbitrators and to risk cost-shifting sanctions if they proceed to trial without improving their positions. ${ }^{132}$

Relatively few of the cases submitted to mandatory arbitration proceed to trial later - fewer, apparently, than would have proceeded to trial in the absence of arbitration. ${ }^{133}$ Even litigants who do initially seek trial following arbitration commonly settle, and lawyers report that the arbitrators' resolution of disputed issues has aided the settlement process. ${ }^{134}$ Surveys of both lawyers and litigants whose cases have been submitted to arbitration reveal a high level of satisfaction, ${ }^{135}$ and courts with mandatory arbitration programs have experienced significant reductions in backlogs and case processing time. ${ }^{136}$

3. Continental Civil Procedure. - In a powerful and provocative study, John $\mathrm{H}$. Langbein has urged the civil procedure of the Federal Republic of Germany as a model for reform. ${ }^{137} \mathrm{He}$ has observed:

132 See, e.g., ILL. REv. STAT. ch. I10, \$§ 2-1012-1020 (1985) (requiring initial submission of a malpractice claim to a panel composed of a circuit judge, a health professional, and an attorney; a party who rejects a unanimous panel determination and then fails to prevail on liability must pay 'costs, reasonable attorneys' fees and expenses of the prevailing party incurred in connection with the review panel and the trial").

${ }^{133}$ See Levin, supra note $\mathrm{I} 28$, at 542 ("A rigorous, empirical study by the Federal Judicial Center of court-annexed arbitration in the Northern District of California and the Eastern District of Pennsylvania found that by referring cases to arbitration the incidence of trial was reduced by approximately $50 \%$."); Peckham, supra note 103, at 270 ; Judicial Council of California, Report and Recommendation on Effectiveness of Judicial Arbitration, in P. EBENER \& D. BETANCOURT, supra note 128 , at A4I, A65-A66 (The statewide trial de novo rate for cases placed on an arbitration hearing list was $1.4 \%$ - although a controlled quantitative study was unavailable, most attorneys, judges, and insurance representatives believed that the program had appreciably diminished trial frequency.).

134 See Judicial Council of California, supra note $\mathrm{I}_{33}$, at A58-A59.

135 Deborah Hensler, who collected "consumer" impressions of the arbitration process for the Rand Corporation, observed, "The explanation for this high level of satisfaction [even among losers] is apparently attributable to litigants' satisfaction with the arbitration procedure itself. We found that most litigants have a simple definition of what constitutes a fair dispute resolution procedure: They want an opportunity to have their case heard and decided by an impartial third party." D. HENSLER, supra note $\mathrm{I} 28$, at II. Hensler also commented that litigants generally conclude that arbitration involves "just the right amount of formality," that litigants "don't view [arbitration] as being undignified or ... careless or, in any sense, a second-class type of process," that these "[l]itigants seem to view arbitration as giving them the same amount of care and fairness as trial did," and that "where there's an edge, the edge seems to be in favor of arbitration." National Conference Report, supra note I28, at 6; accord E. LIND \& J. SHAPARD, supra note 128 , at 59 table 13 (reporting favorable assessments of court-annexed arbitration by attorneys).

${ }^{136}$ Chief Justice Burger noted, "[I]n the first two years after the jurisdictional level [of a court-annexed arbitration program in Philadelphia] was increased to $\$ 10,000$, the entire civil calendar backlog was reduced from 48 months to 21 months." Burger, Isn't There a Better Way?, 68 A.B.A. J. 274, 277 (r982); accord E. LIND \& J. Shapard, supra note 128, at 76; Judicial Council of California, supra note 133, at A65; Note, supra note 128, at 487, 494-95.

${ }^{137}$ Langbein, The German Advantage in Civil Procedure, 52 U. CHI. L. REv. 823 (1985). 
There are two fundamental differences between German and AngloAmerican civil procedure .... First, the court rather than the parties' lawyers takes the main responsibility for gathering and sifting evidence, although the lawyers exercise a watchful eye over the court's work. Second, there is no distinction between pretrial and trial, between discovering evidence and presenting it. Trial is not a single continuous event. Rather, the court gathers and evaluates evidence over a series of hearings, as many as the circumstances require. ${ }^{138}$

As Langbein emphasizes, West Germany avoids the central inefficiency of American civil procedure, the separate pretrial and trial proceedings that commonly require witnesses to tell their stories at least twice. ${ }^{139}$ In addition, judicial control of the proceedings permits the court to examine issues seriatim. A court may focus initially on the issue most likely to prove dispositive, hear the opposing witnesses on this issue, and resolve it - sometimes obviating the need to consider other issues. ${ }^{140}$ Furthermore, judicial control of the trial strongly counteracts the marked tendency of many aspects of American procedure to convert witnesses into partisans and to distort the truth. In general, the noncontinuous, judge-dominated German trial not only is more efficient than the American; it also has a different tone - "the tone not of the theatre, but of a routine business meeting." 141

The proposal that follows draws on West German procedure in shaping what it calls the "first instance" trial. The procedures suggested for this trial, however, include some adversarial safeguards lacking in West Germany. ${ }^{142}$ In addition, the proposal provides for

${ }^{138} I d$. at 826 (footnote omitted).

${ }^{139}$ American witnesses usually must tell their stories more often. Langbein noted "the American practice of partisan interview and preparation, pretrial deposition, preparation for trial, and examination and cross-examination at trial." Id. at 829 .

${ }^{140}$ In the American trial, by contrast, one side typically presents all its witnesses on all potentially relevant issues before the other side is heard. But see FED. R. CIV. P. 42. More importantly, Americans ordinarily must "discover for the entire case. [They] investigate everything that could possibly come up at trial, because once [they] enter the trial phase [they] can seldom go back and search for further evidence." Langbein, supra note 137 , at $83 \mathrm{I}$. In West Germany, not only may the seriatim consideration of issues eliminate the need to explore some anticipated issues, but "if the case takes an unexpected turn, the disadvantaged litigant can count on developing his response in another hearing at a later time." Id. German procedure thus has advantages in its treatment of both anticipated and unanticipated issues.

141 Langbein, supra note 137 , at 831 .

142 Some of the ways in which West Germany combines adversarial and nonadversarial procedures are likely to appear strange to American observers. A German court hears only witnesses nominated by one side or the other (although a party is unlikely to refuse a judge's request that he nominate additional witnesses). Oddly (at least from an American perspective), German lawyers nominate witnesses without conducting any investigation of the facts of their cases and without obtaining any pretrial discovery from their opponents. With rare exceptions, these lawyers rely entirely on what their clients have told them. See id. at $827-28,834$.

This mixed procedure sometimes may result in a less adequate development of the facts than 
a traditional adversarial trial whenever a litigant is sufficiently dissatisfied with the outcome of the first proceeding to risk the expense of a second. The proposal, in short, sacrifices some of the simplicity and expedition of the German system to capture the virtues of a more adversarial procedure; and before presenting the proposal, it is appropriate to explain why.

Langbein notes Lon Fuller's central argument for an adversary system: "An adversary presentation seems the only effective means for combatting th[e] natural human tendency to judge too swiftly in terms of the familiar that which is not yet fully known."143 What Langbein characterizes as the risk of prejudgment, however, is only part of the danger. Regardless of how slowly or how quickly a tribunal reaches its decision, a single fact-gatherer is likely to overlook important considerations and important data. Partly to counteract this tendency, an adversary system divides the labor of marshaling evidence and argument. ${ }^{144}$

Langbein maintains that German civil procedure incorporates sufficient safeguards to obviate Fuller's objections. Most notably, West Germany provides for participation by counsel in the trial and for de novo review of factual as well as legal conclusions on appeal. In practice, however, counsel's participation in the litigation of factual issues at trial is extraordinarily restrained; ${ }^{\mathbf{1 4 5}}$ and West Germany's appellate procedure may not be sufficiently adversarial to check the

either a more adversarial or more inquisitorial procedure would. On some occasions, it also may encourage adversarial gamesmanship of the sort that troubles critics of American procedure. A witness known only to one side whose testimony is likely to favor the other side seems more likely to remain undiscovered in West Germany than in America. Indeed, both opposing lawyers in West Germany may hesitate to nominate a witness when, in the absence of any contact with the witness, each fears that the witness's testimony will be adverse to his position. The court's questioning of other witnesses may reveal the need to hear the testimony of an absent witness, or it may not.

Forbidding independent investigation of the facts seems a Draconian solution to the problems of witness-tampering and "coaching" that arise when lawyers take an active role in gathering and marshaling evidence. Indeed, in America, forbidding contact between potential wititnesses and litigants or their representatives would raise substantial issues under the first amendment's guarantee of freedom of speech. Information provided by even a "coached" witness can further the search for truth; undiscovered information cannot.

143 Fuller \& Randall, Professional Responsibility: Report of the Joint Conference, 44 A.B.A. J. I159, I160 (1958), quoted in Langbein, supra note 137, at 844 .

${ }_{144}$ See Alschuler, Courtroom Misconduct by Prosecutors and Trial Judges, 50 TEx. L. Rev. 629, 637 (1972). I certainly do not deny that American procedure has taken this rationale for an adversary system much too far. See generally M. Frankel, PARTISAN Justice (1980) (criticizing America's excessively adversarial procedures and offering proposals for reform). In general, I favor a "mixed" system of adversarial and nonadversarial procedure that departs to some extent from both the German and American models. See, e.g., infra pp. 1845-54 (discussing how a "first instance" civil trial might proceed).

${ }^{145}$ Langbein noted that "counsel's role in eliciting evidence is greatly restricted" and that "counsel are not prominent as examiners." Langbein, supra note 137 , at 824,828 . 
dangers of an insufficiently adversarial trial procedure. Although appellate tribunals may hear witnesses as part of their review, they need not do so. Instead, they may proceed on the basis of summaries of untranscribed evidence that judges have dictated into trial dossiers. ${ }^{146}$

Much of Langbein's study appears, in fact, to lend color to the customary criticisms of nonadversarial procedure. Langbein describes judges who "constantly look[ ] for the jugular - for the issue of law or fact that might dispose of the case." $147 \mathrm{He}$ observes, "[T]n this business-like system of civil procedure the tradition is strong that the court promotes compromise."148 Indeed, judges are "strongly positioned to encourage a litigant to abandon a case that is turning out to be weak or hopeless."149 The vices of American "managerial judging" appear to be magnified in German civil procedure. ${ }^{150}$

Like other critics of American procedure, ${ }^{151}$ Langbein notes the contrast between adversarial adjudication and "ordinary" decisionmaking. ${ }^{152}$ Nevertheless, some differences between the adjudication of two-party disputes and ordinary decisionmaking may make adversarial procedure more appropriate for one than for the other.

First, adversariness is endogenous in two-party disputes; it arises naturally because both parties want to be heard and want to win. Ordinary decisionmaking is different. A business executive deciding how to respond to a competitor's marketing of a new product or a college senior deciding whether to attend law school might seek out champions of opposing viewpoints and invite them to present conflicting arguments. A judge, however, need not "draft" the adversaries who appear before him. Lawyers oppose each other because they represent real people with real conflicts.

Second, the adjudication of two-party disputes is much more likely than ordinary decisionmaking to involve essentially binary, yes-or-no choices. ${ }^{153}$ A business executive typically confronts a range of options in deciding how to respond to the marketing of a new product by a

146 See id. at $828,856-57$. One wonders whether this German appellate review is as de novo in practice as it is in theory.

147 Id. at 830 .

$148 \mathrm{Id}$. at $83 \mathrm{I}$.

149 Id. at 832 .

150 See supra pp. $183^{2-36}$. Marc Galanter once noted in conversation a circumstance that may have symbolic significance: American judges, perhaps because they are self-conscious about the promotion of settlement, conduct this activity in chambers. German judges, by contrast, initiate and conduct settlement conferences from the bench.

151 See, e.g., M. Frankel, supra note 144, at 116-17; Frankel, The Search for Truth: An Umpireal View, 23 U. PA. L. REV. 1031, 1036 (I975).

152 See Langbein, supra note 137 , at 844 .

153 Indeed, our substantive law typically casts issues in binary form even when it might better authorize a range of options, including that of "splitting the difference." See Coons, Approaches to Court Imposed Compromise - The Uses of Doubt and Reason, 58 Nw. U.L. REv. 750 (1964). 
competitor. He may propose altering his firm's current product, reducing the price of this product, supplementing the current product with a new one, mounting an advertising campaign stressing the virtues of the existing product, mounting an advertising campaign drawing explicit comparisons with the competitor's product, and more. Similarly, a college senior may weigh the virtues of law school, business school, and a job that will enable him to defer the choice between these graduate programs for another year. The executive's task and the senior's task do not closely resemble that of a judge who must decide whether Farmer Brown or Widow Green gets the colt. Although it would be artificial and unproductive to cast most issues of "ordinary" decisionmaking in a binary mode, adversarial procedures may remain appropriate for the resolution of genuinely binary, genuinely disputed issues. ${ }^{154}$

Third and most important, when a business executive or a college senior gives short shrift to an argument about how to respond to a competitor's marketing initiative or about what field to study next year, the person who advanced the argument may reply, "It's your company," or "It's your life." When, however, a judge gives short shrift to Farmer Brown's claim that he owns the colt, the judge does not make a decision about "his" company or "his" life. He makes a decision about Farmer Brown's rights. Decisions ordinarily are the province of the parties most affected by them. Adjudication, however, differs from ordinary decisionmaking in entrusting a choice to a person who is not affected by it, a person who has special obligations to those whose interests are at stake.

Arguments for adversarial procedure have emphasized its effect on the quality of judicial decisionmaking. Because these arguments have been powerful, their proponents may not have considered sufficiently the "process" value of adversariness. Whether or not listening to Farmer Brown's evidence will yield a better decision, the judge owes Farmer Brown a hearing. Affording both sides a full opportunity to present their evidence may not always improve the quality of the outcome; but it is always an essential attribute of fairness, respect, and courtesy.

Of course the contrast between German and American procedures could be overdrawn. German jurists ordinarily do afford litigants ample opportunity to be heard; and before embracing my misgivings about German civil procedure unreservedly, one should note that they do not appear to have been voiced in Germany. ${ }^{155}$ One should note as well that the current American alternative to an informal, judge-

${ }^{154} \mathrm{Cf}$. Fuller, The Forms and Limits of Adjudication, 92 HARv. L. Rev. 353, 395-98 (1978) (arguing that "sufficiently polycentric" issues are not appropriately resolved through adjudication).

155 See Kaplan, von Mehren \& Schaefer, Phases of German Civil Procedure I, 71 HaRv. L. REV. II93, I224 (I958). 
dominated trial is years of waiting in a courthouse queue for a more adversarial trial. Still, a system in which judges strive more vigorously than German judges apparently do to withhold judgment until all the evidence has been heard has its virtues - virtues that may justify a sacrifice of parsimony and expedition.

\section{B. The Plan}

I. "First Instance" and "Second Instance" Trials. - Each of the procedures described above seems deficient in a significant respect. German civil procedure and American "court-annexed arbitration" offer simplified forms of adjudication and point the way toward making adjudicative services more available. Nevertheless, German procedure appears to aggravate the dangers of managerial judging. Court-annexed arbitration does not aggravate these dangers, but it does little to reduce them or to promote the effective judicial control of pretrial activities.

The English use of masters to conduct pretrial proceedings (and, to a lesser extent, the American use of magistrates for the same purpose) differentiates the judicial functions at trial and pretrial proceedings. This separation indicates how Americans can have both a closer judicial supervision of pretrial activity and a more effective corrective for the dangers of judicial case management. Nevertheless, the separation of trial and pretrial functions does not simplify the trial process or make adjudicative services more available.

When one views these procedures together, however, it is necessary only to fit two halves of a picture puzzle together. The assembled puzzle suggests a resolution of some dilemmas of American procedure.

Were pretrial proceedings as closely supervised as they should be, it would not take much to transform these proceedings into a preliminary form of adjudication. To some extent, this preliminary adjudication might be modeled after German and court-annexed arbitration procedures. Similarly, it would not take much to transform courtannexed arbitration, a preliminary form of adjudication, into an effective form of pretrial case management, one that would provide effective judicial control of evidence-gathering and evidence-sharing activity.

Officials who have devised court-annexed arbitration programs have considered how best to fit these programs with existing schemes of judicial case management. For example, these officials have considered whether the parties should conduct discovery before or after the arbitration. Some planners, in fact, have proposed a two-stage process - some discovery before and some after. ${ }^{156}$ The officials do 
not seem to have considered a better preposition - during. The proposal that follows would treat the initial statements of witnesses both as testimony at a "first instance" trial and as discovery for a possible "second instance" proceeding. It would add only one thing to existing forms of preliminary adjudication: pretrial case management. Similarly, it would add only one thing to existing forms of pretrial case management: adjudication. After indicating how the process would work, this Article will consider some objections to it, including the objection that this procedure would unconstitutionally burden the exercise of the right to a jury trial.

2. A Two-Tiered Trial System in Operation. - The story would begin in a familiar way. A lawsuit would be assigned to a judge, and the judge's role at the pleading stage would not differ from the role that judges currently perform. The "first instance" judge would be empowered to pass on the sufficiency of the pleadings, to permit amendments, to dismiss cases in which plaintiffs had failed to state valid claims, and to enter default judgments. ${ }^{157}$ Thereafter, one form of pretrial discovery would occur without direct judicial supervision. Either party could, if he chose, submit written interrogatories to his opponent to learn the opponent's position on specific issues and to identify potential sources of evidence within the opponent's control. A party who received an opponent's interrogatories would answer those to which he had no objection prior to further judicial proceedings.

When a party objected to an opponent's interrogatories, the firstinstance judge would determine the scope of that party's obligation to respond. ${ }^{158}$ After the completion of this preliminary "wave" of discovery, no additional discovery would occur without direct judicial involvement, approval, and participation. ${ }^{159}$

the waste incurred by the reopening of discovery and the relitigation of discovery disputes following medical malpractice arbitration).

157 This proposal does not contemplate assigning the role of first-instance judge to a "parajudge" or a "judge junior grade." The function of the first-instance judge would not be to play picador to a second-instance judge. To the contrary, the first-instance judge ordinarily would make more sensitive decisions than the second-instance judge. The usual function of the secondinstance judge would be to conduct a jury trial after most critical legal issues in a case had been resolved. The functions of the first-instance judge also might require stronger managerial skills and greater sensitivity in interpersonal relations than would the functions performed by the second-instance judge.

Judges selected in the way that American judges currently are selected might not be the ideal figures to perform the functions of first-instance judges. See Langbein, supra note ${ }_{3} 37$, at 848-55. Nevertheless, the apparent success of court-annexed arbitration programs staffed by "parajudges" who sometimes are selected haphazardly counsels against giving extraordinary weight to this objection.

${ }^{158}$ Cf. Manual for Complex Litigation Second $\$ 21.42$ I (1985) ("wave" discovery); $i d$. $\S 2 \mathrm{x} .46 \mathrm{I}$ ("Interrogatories as Preliminary to Other Discovery"); id. \$ 21.463 ("Contention Interrogatories").

${ }^{159}$ In some cases, this closer judicial supervision might reduce the amount of pretrial evidence 
Once a litigant had reviewed his opponent's responses to interrogatories and completed the investigation of his own case, he would prepare a "trial document" listing all witnesses and other sources of evidence that he wished the tribunal to consider during its firstinstance trial. This document would set forth reasons for consulting each of the sources listed. When, for example, a party anticipated that a particular witness's testimony would favor his position, his trial document would offer a brief summary of the witness's anticipated testimony. When a party wished the tribunal to consult a witness or a source of evidence whose testimony or contents were unknown (typically a source within the control of the opposing party), he would set forth his reasons for believing that the source was likely to yield relevant evidence. ${ }^{160}$

After receiving each party's trial document, the judge would hold a conference with the parties and determine what evidence to consider and in what order. ${ }^{161}$ The judge could order that documents in the possession of one party be submitted to an opposing party for inspection so that this party could cull relevant material for submission to the court. The examination of witnesses, however, would occur only before the court. 162

Rules of court would admonish the judge to conduct the firstinstance trial as a single, continuous proceeding whenever possible. ${ }^{163}$ In simple cases, the court would set aside an appropriate period of time and order the witnesses nominated in the parties' trial documents to appear. ${ }^{164}$ Armed with these documents, the judge would conduct

gathering - a development that only some lawyers would be likely to regret. Judges might permit "fishing" only in reasonably promising waters.

160 Cf. Manual for Complex Litigation Second $\$ 2 \mathrm{I} .33$ (1985) (techniques to clarify, narrow, and resolve issues - including "requiring . . . that the parties present a detailed outline of their contentions, with supporting facts and evidence").

In the absence of a justifiable reason for the omission of a source of evidence (or a showing of both an exceptional need and a lack of prejudice to the opposing party), neither the firstinstance nor the second-instance tribunal would ordinarily consider a source not listed in a party's trial document. Of course, as a case progressed, a party could supplement his trial document by adding sources of which he could not have known earlier.

161 FED. R. Crv. P. 26(f) ("Following the discovery conference, the court shall enter an order tentatively identifying the issues for discovery purposes, establishing a plan and schedule for discovery ....").

162 The parties might continue informal investigation on their own, although they would not have any means of forcing an opponent's or a witness's cooperation. I do not propose a restriction on contact between attorneys and witnesses of the sort that exists in West Germany. See supra note $\mathbf{1}_{42}$. Of course the extent and nature of a witness's contact with a lawyer could be considered in evaluating his testimony.

${ }^{163} \mathrm{C} f$. Langbein, supra note $\mathrm{I}_{37}$, at $\$ 26 \mathrm{n} .9$ (describing a similar provision in the West German Code of Civil Procedure, Zivilprozessordnung [ZPO] $\$ 272(\mathrm{I})$ ).

164 The court could refuse to consider a source of evidence listed in a party's trial document only if the document revealed no reason to believe that the source would yield relevant evidence, 
the initial examination of the witnesses. In proposing a somewhat comparable form of adjudication for criminal cases, I noted:

In light of his limited information and his need to remain impartial, a judge's examination of witnesses ordinarily would be cursory. $\mathrm{He}$ would . . . invite the witness's narrative testimony, ask obvious questions, and - prompted by counsel if necessary - intervene when the testimony strayed from relevant issues. A more detailed probing of the witness's testimony would remain the task of the opposing attorneys, each of whom could cross-examine the witness in turn. ${ }^{165}$

By permitting witnesses to give their versions of the "whole truth" in narrative form before opposing advocates tested what they said, this format would promote the dignified treatment of witnesses. In addition, it would "encourage[ ] the emergence of truth, not simply from the clash of two distinct perspectives, but from the interplay of three."166

In exceptional cases, the first-instance trial might be noncontinuous. Noncontinuous proceedings would be appropriate in complex cases, other cases in which it proved unusually difficult to schedule the appearance of witnesses at the same proceeding, and cases in which hearing evidence on one issue might obviate the need to consider other issues. Indeed, in some situations, it might be more convenient for the court and the attorneys to travel to the witnesses than for the witnesses to travel to the court. The court might, in fact, take the testimony of some witnesses by telephone or through audio-visual wizardry (though only on the record and only in the presence of the parties or their lawyers). ${ }^{167}$

Judicial control of the order of proof at trial would permit the court to capture some of the virtues of German civil procedure. Separate issues could be treated separately - for example, by hearing the testimony of opposing expert witnesses immediately after one another. Indeed, the format of the trial might encourage the first-instance judge to exercise an option long recognized (and long disused) in American law - that of appointing an independent expert to supplement the evidence of party-nominated experts. ${ }^{168}$

Professor Langbein recently suggested one reason for the disuse of this power: Until the emergence of "managerial judging," American judges were unlikely to recognize the need for nonpartisan expertise until a trial was underway. Then it was ordinarily too late to make

if the source proved unavailable, or if the court concluded that it would be burdensome and oppressive to require an opposing party or a nonlitigant to produce this source.

165 Alschuler, supra note 5 , at 1004 .

166 Id. at I003.

167 Forcing witnesses to ride airplanes and to wait idly in courthouse corridors is not an indispensible requisite of justice.

${ }^{168}$ See FED. R. EvID. 706; Fink, The Unused Power of a Federal Judge to Call His Own Expert Witness, 29 S. CAL. L. REV. I95 (1956). 
the necessary arrangements. ${ }^{169}$ The submission of the parties' trial documents followed by a conference on what evidence to hear might prompt both an earlier and a clearer judicial recognition of the need for court-appointed experts. Indeed, court rules should direct the judge to consider this option whenever either party nominated an expert witness. ${ }^{170}$

Like a judge in West Germany, a first-instance judge could hear the evidence on potentially dispositive issues at the outset. Indeed, if he were persuaded that a final adjudication of one of these issues would be very likely to resolve the case, he could certify the appropriateness of an immediate, second-instance trial of the issue. Further proceedings might be delayed until this limited second-instance trial had been held. ${ }^{171}$

Because the first-instance judge would not have final adjudicative authority, his participation in settlement discussions would not carry the troublesome message that judicial participation typically carries today. ${ }^{172}$ Most litigants probably would value the judge's input; and in the absence of any objection, he should provide it.

Some litigants, however, might hope to. treat the first-instance adjudication as a final adjudication and might be concerned that a failure to yield to judicial suggestions would affect the judge's later rulings. Other litigants (probably not many) might be uninterested in settlement. A litigant who sought a principled resolution of his dispute should get it without resistance, equivocation, or cajolery by the judge. Accordingly, a litigant who objected to judicial mediation might file a statement of objection with the clerk of court. Once the clerk informed the judge that this statement had been filed, the judge should refrain from mediation. Moreover, as clear assurance against bias or reprisal, both the clerk and the opposing party should be required to keep confidential the identity of the party who had filed this objection. ${ }^{173}$

${ }^{169}$ See Langbein, supra note 137 , at 841 .

${ }^{170} \mathrm{Cf}$. Manual for Complex Litigation Second $\$ 21.48 \mathrm{I}$ (1985) (Disclosure of expert opinions "should be made sufficiently in adaunce of trial . . . for the court to consider, if warranted, selection of a court-appointed expert ....").

${ }^{171} \mathrm{Cf}$. FED. R. Crv. P. 42 (b) (allowing a court to order a separate trial of any claim or issue as long as the right to trial by jury is preserved).

172 See supra pp. $1828-30,1835-36$. A substantial majority of the I90o federal-court litigators surveyed by Wayne D. Brazil agreed that settlement conferences should be conducted by judges other than the judges scheduled to preside at trial. W. BRAzIL, supra note I04, at 5-6. Moreover, "[c]oncern about the propriety of judicial participation in settlement all but evaporates ... when the judicial officer who hosts the settlement conference is not the judge to whom the case has been assigned for trial ...." Id. at 84 .

173 If the danger that court clerks might not preserve confidentiality seemed substantial, rulemakers could turn to a different "masking" procedure - requiring the parties to file a joint statement of objection whenever either party requested this joint objection.

I would not expect litigants to object frequently to judicial mediation. Apart from the situations noted in the text, however, parties whose cases were assigned to judges who routinely 
After gathering and considering the evidence, the first-instance judge would resolve the case and prepare findings of fact and conclusions of law of the same sort that judges currently prepare after nonjury trials. Although most rules of evidence would be inapplicable at first-instance trials, ${ }^{174}$ the judge should be directed not to enter any judgment or to make any finding that a second-instance tribunal limited by the rules of evidence could not reasonably enter or make. No purpose would be served by forcing a litigant to proceed to a second-instance trial simply to obtain the benefit of the rules of evidence. ${ }^{175}$

Either party could appeal the judge's rulings on questions of law (including questions of his abuse of discretion in refusing to consider particular sources of evidence). Jurisdiction over this appeal would be vested in an appellate court, not in a second-instance trial court. The need for appellate proceedings could be obviated by authorizing trials de novo of legal as well as factual issues before second-instance tribunals, but there are at least four reasons for rejecting this procedure.

First, although a full trial de novo might seem the ultimate safeguard against abuse, it would preclude direct review of rulings made by the first-instance judge. Judges may be more careful and less abusive when they sense that other judges are likely to consider the propriety of their actions (rather than simply cast these actions aside and start over). The prospect of direct review tends to deter judicial misconduct in all cases; it does not simply provide a corrective in those cases that happen to reach higher courts. ${ }^{176}$

Second, a trial de novo might itself be followed by an appeal on issues of law. Three tribunals rather than two might be required to pass on a legal issue before it reached authoritative appellate resolution. In many situations, direct appellate review would be a more efficient and more economical procedure.

substituted pressures to settle for the performance of their judicial duties might find the procedure useful.

174 The first-instance judge would pass on claims of privilege and could refuse to hear irrelevant evidence, but he would not decline to consider hearsay or other evidence on the ground that its prejudicial impact outweighed its probative value.

175 In other words, although the judge would not rule on evidentiary objections during the proceedings, a party might argue at the end of the proceedings that some or all of the evidence supporting a particular proposition would be inadmissible at a second-instance trial. Asking a judge to disregard what he had heard would be unrealistic, but determining whether a particular finding would be supported by the weight of the admissible evidence would not be an impossible feat.

176 See S. Bing \& S. Rosenfeld, The Quality of Justice in the Lower Criminal Courts of Metropolitan Boston: A Report by the LAwYers' COMMitTeE For Civil RightS UNDER LAW TO THE GOVERNOR'S COMMITTEE ON LAW ENFORCEMENT AND THE Administration of Justice 96 (I97); Alschuler, Book Appraisal, 66 LAW LibR. J. 122 (1973). 
Third, a full trial de novo would be likely to involve the secondinstance tribunal in issues of case management. For example, the second-instance tribunal might be required to determine whether to order the production of documents that the first-instance judge had not ordered a litigant to produce. The court might find it necessary to explore the issues of the case in depth in order to resolve this issue. ${ }^{177}$ The separation of first-instance and second-instance tribunals is designed to insulate second-instance tribunals from involvement in pretrial case management and thus to limit the risks and dangers of managerial judging. Assigning the appellate function to an appellate court would permit an authoritative resolution of case management issues before a case ever came to the second-instance trial tribunal.

Fourth, the authoritative appellate resolution of legal issues might make the parties more willing to accept the first-instance adjudication as final. It might thereby reduce the number of occasions on which a party found it necessary to subject his opponent to the delays, risks, burdens, and expenses of prolonged trial proceedings.

If an appellate court reversed a ruling by a first-instance trial judge, it could remand the case for further proceedings in the firstinstance tribunal. In some circumstances, however, it might be more appropriate for the court to send the case directly to a second-instance tribunal for trial. When the parties agreed on the appropriate forum for further proceedings, their choice would be respected. When they disagreed, they could argue the issue to the appellate court, which then would determine the appropriate procedure.

In the absence of an appeal on legal issues, the second-instance judge would be required to treat legal rulings by the first-instance judge as settled "law of the case."178 This judge's responsibility for resolving questions of law would be confined to questions that had not arisen during the first-instance proceeding - typically, evidentiary questions and the formulation of instructions to the jury. ${ }^{179}$

A party dissatisfied with the outcome of the first-instance trial could obtain a trial de novo of factual issues in the second-instance tribunal. Procedures at this trial would not differ from those employed in American trials today. In time, if the mode of examining witnesses and other procedures employed in first-instance trials established their worth, they might merit adoption at second-instance trials as well. Nevertheless, when law grows complex, internal reform sometimes is

${ }^{177}$ Direct rather than de novo review of first-instance rulings by the second-instance tribunal would involve the same difficulty.

${ }^{178}$ So would other judges who might consider the case in later proceedings. In the absence of exceptional circumstances justifying collateral review, a party who had failed to appeal an adverse legal ruling should be bound by it thereafter.

${ }^{179}$ Indeed, the second-instance judge might be constrained by decisions that had gone before even in ruling on evidentiary objections and challenged instructions. 
a less promising corrective than establishing new tribunals without barnacles ("courts of equity" rather than "courts of law"). If these new courts succeed, the older courts are likely to get the message. In part, the establishment of first-instance tribunals would reflect this relatively unthreatening approach to reform.

At both the first-instance and second-instance proceedings, costshifting, "loser pays" rules would allocate the parties' litigation expenses. Prior to adjudication by the first-instance tribunal, either party could make a formal offer of settlement. The clerk of court would record this offer without revealing its contents to the judge. This offer would provide the baseline for measuring "loss" under the "loser pays" rule applicable to first-instance proceedings. Specifically, if the tribunal's judgment proved more favorable to a party than his settlement offer, his opponent would be the "loser" and would be required to bear reasonable litigation expenses that the offeror had incurred after the filing of the offer. ${ }^{180}$ Similarly, a party who "lost" the secondinstance trial - in the sense that its outcome was less favorable to him than the outcome of the first proceeding - would bear all reasonable expenses incurred by his opponent in litigating the second proceeding. ${ }^{181}$

${ }^{180}$ For example, the plaintiff might record an offer to accept $\$ 100,000$ in settlement, and the defendant might record an offer to pay $\$ 50,000$. If the plaintiff then recovered only $\$ 25,000$, he would be the "loser" and would be required to bear the defendant's litigation expenses. It could be seen in retrospect that he had forced the defendant to trial unnecessarily. If the plaintiff recovered $\$ 125,000$, the defendant would be the "loser" and would be required to bear the plaintiff's litigation expenses.

If the plaintiff recovered an amount between $\$ 50,000$ and $\$ 100,000$, either of two principles might determine the allocation of litigation expenses. One principle would rest on the proposition that neither party had "Iost" at trial. Neither had forced his opponent to engage in litigation unnecessarily. This principle would suggest that the traditional "American rule" should control; each party should bear his own litigation expenses. The second principle would focus on the midpoint between the two settlement offers ( $\$ 75,000$ in this example). This second principle would treat the defendant as the "loser" if the ultimate award were higher than this amount and the plaintiff as the "loser" if it were lower. Cf. FED. R. CIV. P. 68 (treating an offer in settlement as the baseline for determining loss under a "loser pays" rule but applying the principle inequitably to only one of the parties); Miller, An Economic Analysis of Rule 68, I6 J. LEGAI. STUD. 93 (1986) (arguing that rule 68 "benefit[s] defendants and harm[s] plaintiffs by shifting downward the relevant settlement range").

181 Of course, if a party offered a settlement more favorable to his opponent than the outcome of the first-instance proceeding and the opponent nevertheless persisted in seeking a trial de novo, the settlement offer rather than the outcome of the first-instance proceeding would be the appropriate baseline for measuring "loss" under a "loser pays" rule.

Situations might arise in which the "winner" of a second-instance trial would not have recovered litigation expenses at the first-instance trial - and might in fact have been required to pay the litigation expenses of his opponent. If this party would have been entitled to recover litigation expenses (or would have been relieved of the obligation to pay his opponent's expenses) had the second-instance verdict been returned at the first-instance trial, the second-instance tribunal could include an award of first-instance trial expenses in the winner's recovery. 
Although application of the "loser pays" rule would be unaffected by which party had sought the second-instance trial, "user fees" (or "court costs" reflecting the full expenses of adjudication to the government) would be imposed only on a party who had sought this second trial unsuccessfully. For reasons that this Article has indicated, ${ }^{182}$ the costs of first-instance adjudication ought to be substantially subsidized. In the absence of a finding that a litigant had abused the process, perhaps first-instance litigants should not be required to pay filing fees or court costs at all. Moreover, the reasons for governmental subsidization would extend to a litigant who had found it necessary to resort to a second-instance proceeding to vindicate his rights.

Arguments for subsidization have little force, however, when a litigant already has been afforded one subsidized trial that appears not to have been defective. Moreover, the interests of the party who has not sought review are at stake along with those of the taxpayers. Losing litigants who subject their opponents to the burdens of further proceedings without any better reason than the desire for a second shot ought not be subsidized in this activity. Partly to protect prevailing parties from unnecessary second-instance litigation, ${ }^{183}$ a litigant who sought and then lost a second-instance trial ordinarily ought to be assessed "court costs" reflecting the expenses of the secondinstance proceeding to the government. ${ }^{184}$

First-instance trials would enable litigants to obtain impartial adjudication without the delay and expense of current procedures. Many litigants undoubtedly would find these first-instance proceedings sufficient. Nevertheless, litigants who viewed themselves as "little guys" involved in lawsuits with "big guys" - a category composed in part of personal injury plaintiffs - might be reluctant to accept firstinstance adjudication. The sense that jurors are more likely than judges to favor "the little guy" often might prompt these litigants to insist on second-instance trials. The University of Chicago Jury Project concluded, however, that - contrary to popular impression juries are no more likely than judges to rule in favor of plaintiffs on

182 See supra pp. 181 $1-17$.

183 Shifting the costs of litigation itself tends to achieve this objective, but many of the burdens of litigation are nonfinancial.

184 A court should have discretion to relieve a litigant of this burden when it would work economic hardship and when the litigant had presented issues that were worthy of secondinstance adjudication. As Justice Cardozo once observed, "[H]eavier burdens should be imposed where there is evidence of bad faith or mere dogged perversity." Letter from Benjamin $\mathrm{N}$. Cardozo to H.H. Nordlinger, quoted in G. Hellman, Benjamin N. Cardozo: American JUDGE I50 (I940).

My cost-allocation suggestions are not critical to the proposal for a two-tier trial system. Current American practices - including the rule requiring each party to bear his own litigation expenses - could be retained without eliminating the proposal's value. Like many other of the proposal's features, its cost-allocation suggestions are a subordinate and easily altered detail. 
issues of liability. ${ }^{185}$ At the same time, juries frequently - and in fact usually - award larger damages than judges consider appropriate. ${ }^{186}$

The use of "damages guidelines" of the sort proposed in this Article, ${ }^{187}$ however, could reduce the tendency of "little-guy" litigants to demand second-instance trials. The plaintiffs' personal injury bar would be likely to resist the use of these guidelines at jury trials; but if the content of the guidelines were shaped by recent jury awards, plaintiffs' lawyers might not resist use of the guidelines only at nonjury trials. This use could reduce the capriciousness of damage awards while assuring that judicial awards were, in the aggregate, no lower than jury awards. To the extent that the lawyers for some litigants continued to sense an advantage in jury proceedings, they would be required to weigh this advantage against the delay and expense that these proceedings might involve for their clients.

The procedures described above could be altered to meet needs for distinctive adjudicative services. For example, if both parties wished to obtain a jury trial and did not seek the discovery that a first-instance proceeding would provide, they should be permitted to bypass the first-instance trial altogether. Similarly, if they wished the first-instance tribunal to supply some pretrial services but to stop short of adjudication on the basis of all the evidence, they should be afforded this option. Moreover, just as the first-instance trial could be contracted to meet some special needs, it could be expanded to meet others. In complex cases, a phased series of first-instance proceedings, each preceded by the preparation of a set of trial documents, might prove appropriate.

3. Two Objections - (a) Cost. - In cases in which litigants obtained both first-instance and second-instance trials, the procedures suggested above might make adjudication more complicated and expensive rather than less. ${ }^{188}$ Nevertheless, increased expenditures in cases that traveled the course from filing to second-instance judgment might be more than offset by reduced expenditures in cases that did not go this distance only because impartial adjudication had been afforded at first-instance trials. ${ }^{189}$

185 See Kalven, The Dignity of the Civil Jury, 50 VA. L. REv. I055, I065 (I964).

186 See id.

187 See supra pp. $1825-28$.

188 Videotaping the presentation of evidence at first-instance trials and then using the recorded evidence at second-instance trials when neither party objected (and perhaps even over objection in some circumstances) could, however, reduce the cost of second-instance proceedings. See generally McCrystal \& Maschari, Will Electronic Technology Take the Witness Stand?, II U. TOL. L. REV. 239 (1980).

${ }^{189}$ As far as it goes, the experience of court-annexed arbitration programs supports this optimistic view. Even when first-instance procedures are substantially less thorough, law-bound, and safeguarded than the first-instance procedures proposed here, most cases end after an initial 
The proposed two-tier trial system might indeed cost more than the current trial system - but not because it would involve more complicated procedures in cases resolved by juries. Few cases today survive the boobytraps on the road to jury trial; and although a twotier system would promote more active case management and might thereby defuse some of the bombs, the system would not make jury trials more frequent. If the proposal did increase the costs of America's adjudicative system, it would do so only because it provided simple, straightforward adjudicative services to people who currently do not get them. In a civilized society, the price of supplying these services is worth paying.

(b) Burdening the Right to Jury Trial. - Forty-eight of the fifty states ${ }^{190}$ and the federal government ${ }^{191}$ provide a constitutional right to jury trial in various sorts of civil actions. Several of the procedures suggested here - the requirement that litigants submit to first-instance trials before exercising the right to jury trial, the requirement that they submit to inferlocutory appellate review, and the requirement that they bear the cost of second-instance proceedings if they lose would be likely to make exercise of the right to jury trial less frequent. Nevertheless, these procedures would not exert unconstitutional pressure on the exercise of the right. 192

arbitration. Those that go further usually end before trial. See supra p. 1840. Moreover, even when litigants risk only trivial cost-shifting sanctions by proceeding to second-instance adjudication, few of them do. The relevance of this experience is limited, however, by the fact that current court-annexed arbitration programs are confined to relatively small-stakes cases.

Mandatory arbitration programs for medical malpractice cases are relatively new. If these programs were to lead to a significant reduction in the number of jury trials (even in highstakes cases), that experience would provide strong evidence that a similar reduction in jury trials could be expected under this proposal. Nevertheless, malpractice plaintiffs ("little guys" doing battle with medical professionals and insurance companies) may be unusually likely to demand jury trial. A recent evaluation of a state malpractice-arbitration scheme without costshifting sanctions proclaimed this scheme a "failure" because litigants appealed more than half of the arbitrators' awards. See MacAlister \& Scanlan, supra note 156, at 50r. Nevertheless, this evaluation did not indicate how many of the appeals actually led to trials de novo. In a non-cost-shifting scheme, litigants with little prospect of bettering the arbitrators' awards through litigation may appeal simply in the hope that the threatened imposition of additional litigation expenses will induce settlement on terms more favorable than the initial awards. Whatever the significance of this experience, "little-guy, big-guy" litigation is distinctive. The failure of malpractice arbitration to reduce the demand for jury trial would not demonstrate that an arbitration program applicable to the entire range of civil litigation would have no greater impact.

190 The two exceptions are Louisiana and Colorado. See James, Trial by Jury and the New Federal Rules of Civil Procedure, 45 YALE L.J. 1022, 1022 \& n.4 (1936).

191 U.S. CoNST. amend. VII. Unlike the right to jury trial in criminal cases, see Duncan v. Louisiana, 391 U.S. 145 ( 1968 ), the right to jury trial in civil cases has never been "incorporated" in the due process clause and made applicable to the states.

192 At the same time, these procedures are designed to confine civil juries to the role reasonably regarded as essential under federal and state constitutions and thus to limit the overproceduralization that infects our jury-trial system. 
In Ludwig v. Massachusetts, ${ }^{193}$ a criminal defendant challenged the constitutionality of a state procedure that required him to submit to a nonjury trial before he could exercise his constitutional right to jury trial. The Supreme Court rejected his challenge. Although Ludwig does not itself establish the constitutionality of the two-tier system proposed here, the circumstance that differentiates the proposed system from the one upheld in Ludwig should not lead to a different result.

The Court's opinion in Ludwig emphasized that the defendant had an almost cost-free option. He could have submitted to a finding of guilt in the first-instance proceeding and then obtained a trial de novo before a jury. The defendant was not required to "pursue, in any real sense, a defense at the lower tier."194 A civil litigant in the twotier system proposed in this Article would not have the same option. If this litigant's opponent wished to discover evidence during the firstinstance trial, the litigant would be required to supply it.

The obligation to present evidence during a first-instance trial differentiates the system proposed here from the one challenged in Ludwig. Nevertheless, this circumstance itself indicates the untenability of a claim that the proposed procedure would violate the Constitution. It is too late in the twentieth century to assert that requiring a civil litigant to disclose evidence to his opponent in advance of a jury trial unconstitutionally burdens the exercise of his right to that trial. 195 Ludwig established that the entry of judgment at a firstinstance proceeding does not unduly burden the exercise of the right, and the suggested first-instance procedure adds to the entry of judgment only a requirement of compliance with discovery obligations. ${ }^{196}$

Similarly, ordering losing litigants to bear court costs is a wellestablished practice, and so is allowing interlocutory appellate review of some legal rulings in advance of trial. The proposed system would extend these practices, but not to the point at which they would operate unfairly.

Were government to attempt to "sell" jury trials at a profit, the practice undoubtedly would violate the Constitution. ${ }^{197}$ Nevertheless, the Supreme Court generally has permitted governments to recoup

${ }^{193} 427$ U.S. 6 I8 (I976).

194 Id. at 626.

195 See FED. R. Crv. P. 26-37 (concerning depositions and discovery).

196 In Callan v. Wilson, I27 U.S. 540 (I888), the Supreme Court invalidated a two-tier criminal trial system on the ground that it infringed the right to jury trial. In Ludwig, however, the Court confined Callan to federal criminal prosecutions - those in which the distinctively phrased jury trial guarantee of article III applies. See U.S. Const. art. III, $\$ 2$ ("[T]he Trial of all Crimes, except in Cases of Impeachment, shall be by Jury . . . "); Ludwig, 427 U.S. at 629-30.

${ }^{197}$ See Van Alstyne, The Demise of the Right-Privilege Distinction in Constitutional Law, 8I HARV. L. REV. 1439, I445-49 (I968). 
expenditures caused directly by the exercise of constitutional rights. ${ }^{198}$ The Court has read the Constitution to require governmental subsidization in only a few situations; even then, it has mandated subsidization only for the indigent. 199

One can imagine situations in which the Court probably ought to go further; an unqualified declaration that all except the indigent can be required to pay their way in exercising constitutional rights might be too broad. ${ }^{200}$ Nevertheless, constitutional rights ordinarily are satisfied when governments refrain from interference; they do not imply an obligation to subsidize. The reasonable imposition of court costs proposed in this Article would not justify a departure from that principle. ${ }^{201}$

${ }^{195}$ See Cox v. New Hampshire, 312 U.S. 569, 576-77 (I94I) (upholding a license fee to recoup governmental expenses caused by speech). But $c f$. Murdock v. Pennsylvania, 319 U.S. I05 (I943) (holding a "tax" on speech invalid). For criticism of the Supreme Court's approach, see Goldberger, $A$ Reconsideration of Cox v. New Hampshire: Can Demonstrators Be Required to Pay the Costs of Using America's Public Forums?, 62 TEx. L. REv. 403 (1983).

199 Compare Gideon v. Wainwright, 372 U.S. 335 (I963) (indigent criminal defendant entitled to appointed counsel), with Fuller v. Oregon, $4 \mathrm{I} 7$ U.S. 40 (I974) (defendant, no longer indigent, required to reimburse the state for the costs of counsel). See also Ortwein v. Schwab, 4ro U.S. 656 (1973) (per curiam) (indigent not entitled to waiver of an appellate filing fee in a civil case); United States v. Kras, 409 U.S. 434 (1973) (indigent not entitled to waiver of a filing fee in a bankruptcy action); Boddie v. Connecticut, 401 U.S. 37 I (I97I) (indigent entitled to waiver of a filing fee in a divorce action).

200 For example, although our legal system requires nonindigent criminal defendants to pay their attorneys' fees even when they are acquitted, requiring acquitted defendants to pay the costs incurred by the government as a result of their exercise of the right to jury trial might seem unconscionable. Cf. 28 U.S.C. $\$$ I 918 (b) (1982) (permitting the imposition of court costs only on convicted defendants). An imposition of court costs on acquitted defendants might in fact violate the sixth amendment guarantee of jury trial. Forcing these defendants to answer unproven criminal charges would not have been done for their benefit.

In deciding whether a similar right of subsidization for nonindigent litigants should extend to losing parties in second-instance civil proceedings, an examination of the history of the civil jury is instructive. The common law right to jury trial did not include the right to a cost-free trial or even to a subsidized trial. To the contrary, officeholders obtained substantial profits by exacting fees from litigants at approximately 40 different stages of the proceedings. The requirement that the losing party bear the winner's costs ordinarily placed the ultimate burden of these fees on nonprevailing parties. See C. Francis, Strategy and Institution: An Analysis of Common Law Debt Collection 38-40, 87-107 (r986) (unpublished manuscript); see also M. Blatcher, The Court of King's Bench 1450-r550, at 34-46 (1978); J. SaYer, Law of Costs (2d ed. I777).

Various statutes relieved paupers of the obligation to pay costs but sometimes only on the condition that they "suffer such other punishment as appeared reasonable to the judges." $4 \mathrm{~W}$. HoldswORTH, A HISTORY OF ENGLISH LAW 538 (3d ed. 1945). Holdsworth reports, "In the seventeenth century the practice appears to have been to tax the costs, and, if the costs were not paid, the court could adjudge that the plaintiff be whipped." Id. Although this history need not control a modern court's interpretation of the right to jury trial in civil cases, the common law history obviously poses no obstacle to upholding the reasonable imposition of court costs on nonprevailing parties.

201 In criminal cases, the Supreme Court has countenanced astonishing burdens on the 


\section{CONCLUSION}

Apart from questions of constitutionality, critics might object that the proposed procedures could lead to a substitution of nonjury for jury trials in all but a small minority of civil cases. To the extent that litigants found a simpler, less burdensome form of adjudication more attractive, however, the displacement might not be regrettable. The jury would remain available as a safeguard or "backstop." It would perform the historic role that the Supreme Court emphasized in Duncan v. Louisiana ${ }^{202}$ - that of guarding against "the compliant, biased, or eccentric judge."203

More importantly, critics who feared that this proposal could lead to the demise of the civil jury apparently would have missed a secret that almost everyone knows - a secret that the first half of this Article rebroadcast. The civil jury, if not yet dead, is in extremis. It has been brought to its deathbed by existing procedures, not by the procedures proposed here. This institution has been bludgeoned by discovery wars, lengthy queues, high attorneys' fees, satellite hearings, anti-trial conferences, and the world's most extensive collection of

exercise of the right to jury trial. It has upheld even waivers of that right induced by the threat of capital punishment. See, e.g., Brady v. United States, 397 U.S. 742 (I970); North Carolina v. Alford, 400 U.S. 25 (1970); see also Bordenkircher v. Hayes, 434 U.S. 357 (1978). But see United States v. Jackson, 390 U.S. 570 (1968) (invalidating a clause of Federal Kidnapping Act because that clause permitted a death sentence only after a jury trial). After upholding the gratuitous and almost unlimited pressures of current plea bargaining practices, it would seem unconscionable (and hypocritical) for the Court to balk at the limited, cost-related consequences that this Article has suggested should follow unsuccessful exercise of the right to jury trial in civil cases.

202391 U.S. 145 (1968).

${ }^{203} I d$. at 156 . Under the proposed procedure, a losing litigant could seek a jury trial when he sensed that the danger noted in Duncan had materialized at a first-instance proceeding. He would be unlikely to demand a jury in the absence of a reason to believe that a jury's assessment of the evidence would differ from that of the first-instance judge.

One caveat to this conclusion merits mention. In a case in which the stakes were very high, even a small chance of victory at a second-instance proceeding might lead a losing litigant to run the risk that he would bear the expenses incurred by the government and his opponent in conducting this proceeding. A 10\% chance of recovering one billion dollars could justify a $90 \%$ chance of not recovering this sum but of paying ten million dollars in court costs and litigation expenses instead. Nevertheless, very-large-stakes cases tend to be complex cases, and the extent to which the constitutional right to jury trial extends to complex civil cases remains unsettled. Compare In re United States Fin. Sec. Litig., 609 F.2d 4 I I (gth Cir. 1979) (complex civil cases are not exempt from the jury-trial requirement), cert. denied, 446 U.S. 929 (1980), with In re Japanese Elec. Prod. Antitrust Litig., 63I F.2d 1069 (3d Cir. 1980) (the seventh amendment does not guarantee a jury when the proceedings are so complex as to render the jury ineffective). Were the right to jury trial held inapplicable to complex cases and were the first-instance trials proposed in this Article to prove fair and appropriate mechanisms for resolving these cases, state and federal legislatures might consider converting these first-instance proceedings into final proceedings. After an appropriate period of experimentation, legislatures also might consider restricting the right to second-instance trials in equitable actions (proceedings to which the right to jury trial has never extended). 
cumbersome procedures. In recent decades, as judges and scholars have decried the litigation explosion, as civil filings have increased, as the number of lawyers per capita has nearly doubled, and as substantive rights have expanded at an astonishing pace, the limited evidence available suggests that the absolute number of jury trials in the state courts has declined. ${ }^{204}$ In the federal courts, although there has been no decline, the percentage of cases terminated during or after trial has fallen from 15.2 in 1940 to 10.3 in 1960 to 6.5 in $1980^{205}$ to 5.0 in I $984 .{ }^{206}$ In our current system of civil procedure, these figures reflect not merely the demise of the jury but also the demise of adjudication. ${ }^{207}$ A two-tier trial procedure would not save the jury, but it might revive America's moribund system of adjudication.

The proposal advanced in this Article has been sketchy and tentative. It marks only one possible path toward the correction of our unworkable trial procedures. Nevertheless, judges, court administrators, rulemakers, and others should abandon their current emphasis on hammered settlements and other shortcuts and renew our society's commitment to the provision of basic adjudicative services.

In a more civilized society, the extensive' rationing of adjudication by price and queue would not assure wrongdoers that they always could "settle" and profit from their wrongs. In this society, a right would be something that one gets, not merely something that one has. People would know that they could take their disputes to the courts and that the courts would resolve them. With this assurance, people might be less likely to take their disputes to the streets or to the subways.

204 See supra pp. 1819-20.

${ }^{205}$ See supra p. I8Ig \& note 51.

${ }^{206}$ See supra p. 1829 \& note 90 . When these figures are placed on a graph, they form a straight line. If projected into the future, the line suggests that the federal courts will conduct no trials at all after the year 2000 . Of course the line is likely to curve before it hits bottom. Nevertheless, the descent seems to be continuing with great rapidity.

207 Adjudication does occur in rulings on motions for summary judgment, in other pretrial rulings, and in "alternative dispute resolution" proceedings. Nevertheless, one should not alibi Ringling Brothers' failure to perform in the big top by pointing to its diversions and sideshows. 